\title{
Exiting the Whirlpool? \\ Pan-Africanism Caught in the \\ Crossfire of Identity and Globalization
}

Tatah Mentan

Abstract

Africa's peoples and cultures have been subject to dramatic external interventions and influences enmeshing them firmly within the world capitalist system. The successive population decapitalizations, conquests, colonizations, and associated cultural imperialisms of Arab and European, Islam and Christianity, the slave trade, and more recently the rapid 'modernization' and spread of capitalist consumerism have all transformed and internationalized cultures, conceptualizations, and commodities. This increasingly powerful process of convergence has captured the African popular imagination to the extent that 'globalization' is as much a subject of media interest as of academic enquiry.

Yet convergence and globalization are not all-embracing, unidirectional, and homogenizing processes. Rather, their impact varies greatly in extent and intensity over time, across space, and within and between cultures and social classes. Moreover, countermovements, both conscious and unpremeditated, are occurring simultaneously. Pan-Africanism has been one such countermovement. How can a renascent Pan-Africanism assert its identity within these global networks of interconnections?

The overall aim of this study is therefore to examine the ways global forces impact upon African societies; the ways in which African societies have an impact upon the globalization process; and the comparative, cross national and cross cultural comparison of global processes as they relate to Africa. Will the Pan-African ideal help the continent to exit the whirlpool of decapitalization and deterritorialization by the ravaging forces of globalization? If so, how? These are the challenging questions facing Pan-African intellectuals and which this paper attempts to grapple with. 


\section{Introduction}

On the verge of the twenty-first century, Africa is in upheaval. The limits of imported paradigms to explain such phenomena have been exposed. Worse yet, they have brought conflicts and devastation, accentuated regression, and distorted the African concept of identity and development. These imported structures disintegrated at the end of the twentieth century and leaders in many regions of the continent are being swept away by events instead of imposing their will on them. This existential situation is attributed to the loss of the power and glory of the Pan-African ideal.

The result of this upheaval is that the history of Africa is a history of domination by the Western political economy, which created and now dominates and operates the modern world system. This assertion raises some pertinent questions. First, does this statement stand up to historical facts? Two, does it still hold true today in the era of globalization? Three, has there been any resistance to this situation by African nationalists or has there been any attempt to assert Africa's identity in the face of these western incursions? And, finally, what have intellectuals said about the existential situation and the re-assertion of African identity?

The process of Western incursions, capture, exploitation, and domination of Africa can be divided into the following phases:

- Population Decapitalization and Anarchic Plunder

- Colonial Imperialism

- $\quad$ Birthing Pan-Africanism

- Killing Pan-Africanism

- $\quad$ Africa 'in' the Global Village?

- $\quad$ Exiting the Whirlpool

Each phase was manifested both in the Western nations and in Africa and every capitalist transformation in the West was reflected in the political economy of Africa. These reflections of Africa's asymmetrical integration into the world capitalist system have been deemed 'development', 'civilizing missions' or 'modernization'. 


\section{Theorizing globalization and development}

The globalization and world-systems theories, and to some extent the dependency approach, take into account the most recent economic changes in world structure and relations that have occurred in the last two decades; for example: (a) the adoption of more flexible mechanisms in terms of exchange rate control; (b) futures trade speculation, reinforced by the more flexible use of modern technology in information, computers, and communication systems; (c) the computer revolution of the eighties; (d) the Internet system which allows for more rapid and expansive communication. The fundamental premise of globalization is that an increasing degree of integration among societies is necessary. However, there is less consensus on its fundamental organizing principles and laws of motion. Neoclassical economic theories based on comparative advantage (Klein, Pauly and Voisin 1985), international relations approaches that stress geopolitics (Keohane 1993, Thompson 1991), and world-systems perspectives that emphasize 'unequal exchange' (Amin 1989, Frank 1979, Wallerstein 1991) offer contrasting models of the international system.

Through the process of globalization more nations are depending on worldwide conditions in terms of communication, the international financial system, and trade. Therefore the world scenario is more integrated in international economic transactions (Sunkel 1995, Carlsson 1995, Scholte 1995). Effects and influences from these integrational aspects can be studied from two major perspectives: (a) countries' external level (the systemic approach); and (b) domestic or internal conditions within nations (sub-systemic approach). In this last mentioned case, the units of analysis correspond to national variables of economic growth or social indicators.

In terms of the globalization process that is taking place under current worldwide economic conditions, two main topics in international political economy are: (a) the structure of the international economic system; and (b) how this structure has changed. ${ }^{1}$ The basic claim is that international connections, roles, and relationships are important variables in any analysis which tries to explain various dimensions of development. ${ }^{2}$

The main areas under dispute concerning globalization theory 
relate to four main aspects: (a) The fact that countries can have more than three levels of placement: core, semiperiphery, and periphery countries (Schott 1986); (b) The positional characteristics of several countries in terms of sharing the same patterns of relationships can be related to the 'clique' characteristics with other nations at a regional level (Snyder 1989); (c) Even inside the same position within international relations, the features of countries vary in terms of the size of their economies, internal effective demand, export structure, and level of historical and/or current economic growth (Smith 1992); and (d) There is strong evidence that the patterns of economic concentration among nations especially in the fields of international trade and financial systems, are related to the dependent development patterns claimed by the neostructuralist authors (Cardoso 1992). ${ }^{3}$

The theory of globalization emerges from the global mechanisms of greater integration with particular emphasis on the sphere of communications and economic transactions. However, one of the most important characteristics is the emphasis on cultural aspects and their communication worldwide. One of the most important factors is the increasing flexibility of technology to connect people around the world. ${ }^{4}$ The main aspects can be delineated as follows:

a) Global communications systems are gaining in importance, and through this process all nations are interacting much more frequently and easily, not only at the governmental level, but also within the citizenry;

b) Even though the main communications systems are operating among the more developed nations, these mechanisms are also spreading among the less developed nations. This fact will increase the possibility that marginal groups in poor nations can communicate and interact within a global context using the new technology, and therefore can integrate themselves with the 'global village'; 5

c) The advances in communication are also more accessible to local and small businesses. This situation is creating a completely new environment for carrying out economic transactions, utilizing productive resources, equipment, trading products, and taking advantage of 'virtual monetary mechanisms'. From a cultural 
perspective, the new communication products are unifying patterns of communications around the world, at least in terms of economic transactions under current conditions;

d) The concept of minorities within particular nations is being affected by these new patterns of communication. Even though these minorities are not completely integrated into the new world system of communications, the powerful business and political elites in each country are a part of this interaction around the world. Ultimately, the business and political elite continue to be the decision makers in developing nations;

e) Social and economic elements under the influence of the current phenomenon of globalization are determinant circumstances which affect the standards of living of every particular nation. ${ }^{6}$

The assumptions of the theory of globalization can be summarized in three principal points. First, cultural and economic factors are the determining aspect in every society. Second, under current global conditions, it is not as important as previously thought to use the nation-state category as a unit of analysis, since global communications and international ties are making this category less useful. Third, with more standardization in technological advances, more and more social sectors will be able to connect themselves with other groups around the world, which implies faster and easier communications and economic transactions. This situation will affect the dominant and non-dominant groups from each nation. ${ }^{7}$

In more specific terms, it is important to mention that globalization theory implies a key element concerning integration - integration regarding international trade, the international financial system, technology and communications, and cultural values from the more developed countries (DeMar 1992, Carlsson 1995). Economic integration at the systemic level - among countries - means stronger worldwide relationships. At the sub-systemic level - within countries - it implies social and economic integration from the different social sectors (Sunkel 1995). At the systemic level there are some nations which are able to achieve more integration into the new world economic conditions than other countries. At the sub-systemic level there are some social sectors which integrate themselves into the new economic dynamic derived especially from 
the economic growth, and sectors which become more marginalized in social terms (Sunkel 1995, Paul 1996, Scholte 1996).

While the term globalization is now currently utilized, especially following the technological revolution in comunications ${ }^{8}$ and the creation of cyberspace, one of the first major arguments on 'Globalization of the Markets' can be found in a 1983 article by Theodore Levitt in the Harvard Business Review. ${ }^{9}$ The functionalist aspect of globalization is what distinguishes it from the mere notion of internationalization, which refers to a quantitative process but not necessarily to an epochal shift of a more qualitative kind. According to Peter Kickens, globalization processes are qualitatively different from internationalization processes. They involve not merely the geographical extension of economic activity across national boundaries, that is internationalization, but also the functional integration of such internationally dispersed activities. ${ }^{10}$

In addition to globalization, the other main theories of development are: (i) modernization; (ii) world systems; and (iii) dependency. From a more comparative point of view, the theory of globalization coincides with some elements of the theory of modernization. These schools hold that the main patterns of communication and the tools to achieve better standards of living originated in those more developed areas.

The modernization perspective differs from the globalization approach in that the former follows a more normative position - stating how the development issue should be solved. The latter reinforces its character as a 'positive' perspective rather than a normative claim. ${ }^{11}$ Globalization theories emphasize cultural and economic factors as the main determinants which affect the social and political conditions of nations, which is similar to the 'comprehensive social school' of Max Weber's theories. ${ }^{12}$ From this perspective, the systems of values, beliefs, and the pattern of identity of dominant and the subordinate groups within a society are important elements to explain national characteristics in economic and social terms. ${ }^{13}$ For the globalization position, this statement from the Weberian theory from the 1920s must apply to current world conditions especially in terms of the diffusion and transference of cultural values through communication systems that are increasingly affecting many social groups in all nations. 
It is clear that the globalization and world-systems theories take a global perspective as the unit of analysis, rather than focusing strictly on the nation-state as was the case in the modernization and dependency schools. The contrasting point between world-systems theory and globalization is that the first contains certain neo-Marxist elements, while the second bases its theoretical foundations on the structural and functionalist sociological movement. Therefore, the globalization approach tends more toward a gradual transition rather than a violent or revolutionary transformation. For globalist authors, the gradual changes in societies become a reality when different social groups adapt themselves to current innovations, particularly in the areas of cultural communication and the economic sphere. ${ }^{14}$

Today, the main aspects under study from the globalization perspective are: a) new concepts, definitions and empirical evidence for hypotheses concerning cultural variables and their change at the national, regional and global level; b) specific ways to adapt the principles of 'comprehensive sociology' to the current 'global village' atmosphere; c) interaction among the different levels of power from nation to nation and from particular social systems which are operating around the world; d) how new patterns of communication are affecting minorities within each society; e) the concept of autonomy of state in the face of increasingly flexible communication tools and international economic ties, which render obsolete the previous unilateral effectiveness of national economic decisions; and f) how regionalism and multilateral agreements are affecting global economic and social integration.

\section{Population decapitalization and anarchic plunder}

Since time immemorable there has been interplay between Southern Europe and North Africa. Portugal was the first to venture outside her own shores towards Africa. Contact between Portugal and West Africa was first made in 1446. For Europe this first contact later proved to be a watershed event. For Africa it was a prelude to a descent to hell. The Africans traded with the newcomers with reckless abandon. For their gold they received silly trinkets. But the Portuguese adventurers had in mind another form of trade that was 
potentially more lucrative. They wanted to capture slaves for markets in Portugal and Spain.

However, it was the aftermath of the voyages of Columbus to the so-called New World that brought anathema to the African continent. One of the outcomes of these voyages was the creation of the 'triangular trade' system in which manufactured articles flowed from Europe to Africa; slaves from West Africa to America; and sugar, gold, silver, indigo, tobacco, and other products flowed from America to Europe.

\section{Atlantic Slave Trade}

Slavery remains a crucial area of study in the history of North America. But this history of slavery is a part of a larger operation that exported people from the African continent to regions throughout North and South America for more than 400 years. Some historians estimate that more than 15 million Africans were forced to leave Africa to cross the Atlantic to be sold into slavery. In addition, millions of other Africans lost their lives during slave raids or during their forced removal to coastal forts where they would be transported to the Americas. This trade had devastating economic and social effects on Africa: it crippled economic potential, destroyed political systems, broke down moral and civic practices, integrated Africans into the international division of labour and exhausted human resources.

Europeans had been involved in trade with Africa before the Atlantic Slave Trade began. In the 1400s, Prince Henry of Portugal began an initiative to seek out direct sea routes to gain access to the gold trade in West Africa, as well as trade in Asia. In the fifteenth century, European countries were seeking trade routes with Asia, particularly the spice islands of south-east Asia. What began as a quest for trade in gold and spices, ended up becoming a trade network exporting African slaves, which would continue for more than 400 years.

The first slaves brought to Portugal came in 1444 from Northern Mauritania. From Mauritania, the Portuguese moved their way down the western coast of Africa, establishing contact all the way down to the Cape of Good Hope and around to the other side of Africa. 
Through these contacts, the Portuguese initiated trade relations that grew into the Atlantic Slave Trade. The Dutch, French, Spanish, and British soon followed in their footsteps.

The interaction of European powers and Africans varied from region to region. What may have seemed like a diplomatic exchange of citizens in the beginning grew into a system of slave trade that devastated the Kongo Kingdom. In 1483, the Portuguese began a long-term relationship with the Kongo Kingdom (see map below to locate the Kongo Kingdom.) Portuguese explorer Diogo Cão sailed via the Atlantic Ocean down into the mouth of the Congo River. Upon reaching the Kongo Kingdom, he took Kongo emissaries back with him to Portugal, who later returned to Africa with European soldiers, priests, and goods. This was the beginning of a strong trade relationship with the Kongo that exported slaves and ivory in exchange for European luxury goods and guns.

Although historians know that slavery existed in some places on the African continent prior to the Atlantic Slave Trade, the ways in which African slavery compared to and interacted with the exportation of African slaves across the Atlantic remains a topic of much discussion and debate. Many historians suggest that slavery as practiced in different areas in Africa was not the same as 'chattel slavery' which was practiced in the Americas. For example, slaves in some West African societies filled different positions in society, including positions of important responsibility; they were not restricted to hard labour. It is also not easily determined to what extent the Atlantic Slave Trade fueled and transformed the practice of slavery within Africa. However, there is no doubt that the Atlantic Slave Trade brought dramatic changes on a global scale throughout the African continent as well as the Americas.

The Atlantic Slave Trade essentially worked like a triangle between Africa, Europe, and the Americas. Trade goods, such as guns and textiles were sent out of Europe and traded in Africa for slaves. The slaves were crammed into ships that crossed the Atlantic in order to provide labour for large plantations in North and South America, which were growing cotton, sugar cane, and tobacco. These regions of North and South America were European colonies for much of the Atlantic Slave trade and served to provide raw materials to Europe for manufacturing. Slaves were sent from Africa not only to North 
America, but also to the islands of the Caribbean and the east coast of South America.

To speak about the degree of human suffering that took place during the Atlantic Slave Trade is not an easy task. Slaves were kept living in abominable conditions in dungeon fortresses along the coast of western Africa until the time that they were sent out to sea on large boats headed for the Americas. They were kept in chains and left to lie on their backs on slave ships while crossing the Atlantic Ocean. This long and treacherous journey has become known as the 'Middle Passage'. Historians estimate that as many as 20 percent died while crossing the ocean.

Estimates of the total human loss to Africa over the four centuries of the transatlantic slave trade range from 30 million to 200 million. At the initial stage of the trade parties of Europeans captured Africans in raids on communities in the coastal areas. But this soon gave way to buying slaves from African rulers and traders. The vast majority of slaves taken out of Africa were sold by African rulers, traders and a military aristocracy who grew wealthy from the business. Most slaves were acquired through wars or by kidnapping. The Portuguese Duatre Pacheco Pereire wrote in the early sixteenth century after a visit to Benin that the kingdom 'is usually at war with its neighbours and takes many captives, whom we buy at twelve or fifteen brass bracelets each, or for copper bracelets, which they prize more'.

European slave buyers made the greater profit from the despicable trade, but their African partners also prospered. Africa's rulers, traders and military aristocracy thus protected their interest in the slave trade. They discouraged Europeans from leaving the coastal areas to venture into the interior of the continent. European trading companies realised the benefit of dealing with African suppliers and not unnecessarily antagonising them. The companies could not have mustered the resources it would have taken to directly capture the tens of millions of people shipped out of Africa. It was far more sensible and safer to give Africans guns to fight the many wars that yielded captives for the trade. The slave trading network stretched deep into Africa's interior.

Contact with Europe opened new images of the world for the African elite and presented them with products of a civilisation which as the centuries passed became more technologically 
differentiated from their own. The slave trade whetted their appetite for the products of a changing world.

A number of factors contributed to ending the Atlantic Slave Trade officially in the early 19th century after it had continued for over 400 years. Among these was a growing public revulsion against the slave trade. One important person in bringing about this change was Olaudah Equiano, born in present-day Nigeria and later taken to the Americas as a slave. During his life, he was able to buy his freedom (a rare occurrence) and wrote about his experience of being captured and sold into slavery. His writing had a profound effect on public opinion on the slave trade.

In addition, between 1801 and 1803, there was a successful slave revolt in the Caribbean island nation of Haiti, which shook people throughout the Americas as they realized that the system of slavery could be challenged and overthrown.

Finally, the Industrial Revolution in Europe and North America, which occurred simultaneously with the Atlantic Slave Trade, was fueling a growing demand for free rather than servile labour. In the early years of the Industrial Revolution, cheap raw materials, such as cotton, produced by slave labour in the Americas were essential, but by the 19th century continued industrial expansion was dependent on a flexible and mobile labour force. Consequently, many European and American industrialists who supported the slave trade in the 18 th century changed their minds when slavery was no longer an economic benefit.

In 1807, Britain became the first European nation to ban the slave trade. France, Holland, and the United States (the latter only in 1864) thereafter passed legislation banning the slave trade. However, since Spain and Portugal did not follow this example, African slaves continued to be sent to countries in South America until near the end of the 19 th century.

In an attempt to stop the slave trade, Britain dispatched war ships to intercept slave ships off the west coast of Africa. When intercepted, the freed slaves were often sent to Liberia ('Liberty') and Sierra Leone (capital city of Freetown) in West Africa, which were established by US and British anti-slavers as havens for freed slaves.

When Britain abolished the slave trade in 1807, however, it not only had to contend with opposition from white slavers but also from 
African rulers who had become accustomed to wealth gained from selling slaves or from taxes collected on slaves passed through their domain. African slave-trading classes were greatly distressed by the news that legislators sitting in parliament in London had decided to end their source of livelihood. But for as long as there was demand from the Americas for slaves, the lucrative business continued. A consequence of the ending of the slave trade was the expansion of domestic slavery as African businessmen replaced trade in human chattel with increased export of primary commodities. Labour was needed to cultivate the new source of wealth for the African elites.

Had Europe not decided to end the slave trade and the New World agriculture ceased demanding chattel labour, the transatlantic trade might still be rolling today. The ending of the obnoxious business had nothing to do with events in Africa. Rulers and traders there would have happily continued to sell humans for as long as there was demand for them. One can only imagine how much more determinedly African merchants would have clung on to the business as goods offered by European buyers became more attractive with changes in Western technology. How many souls would African chiefs have been prepared to trade for a television or a car? It is a disturbing thought.

To highlight the role of the African elites in the slave trade is not to argue the obvious that they were morally depraved like the Europeans who bought slaves from them. It is to show that the corrupt leadership that undermines democracy and economic development in African countries today has a long history. The selfishness and disregard for the welfare of fellow humans manifest in the sacking of national resources by modern African leaders also motivated the pillaging of the human resources of the continent in times past.

\section{Emergence of corrupt African ruling classes}

Some African writers, seeking to maximise the culpability of Europe in the slave trade, minimise the part played by African rulers and traders or explain it as the result of white trickery. Such distortion of history may make the moral case against European imperialism seem sharper, but it does nothing to aid the understanding by Africans of a critical period of their history. African slavers acted 
out of their own volition and for their self-interest. They took advantage of the opportunity provided by Europe to consume the products of its civilisation. The triangular slave trade was a major part in the early stages of the emergence of the international market. The role of slave-trading African ruling classes in this market is not radically different from the position of the African elite in today's global economy. They both traded the resources of their people for their own gratification and prosperity. In the process they helped to weaken their nations and dim their prospects for economic and social development.

The slave trade had a profound economic, social, cultural and psychological impact on African societies and peoples. It did more to undermine African development than the colonialism that followed it. Through the trade the continent lost a large proportion of its young and able bodied population. Guyanese historian Walter Rodney cites one estimate showing that while Europe's population more than quadruped between 1650 and 1900, Africa's population rose only by 20 percent during the same period. The loss of workforce was not more serious than the damage to the social and economic fabric of the society and the undermining of the confidence of Africans in their historical evolution.

The Transatlantic Slave Trade and slavery were major elements in the emergence of capitalism in the West. As Karl Marx noted, they were as pivotal to western industrialisation as the new machinery and financial systems. Slavery gave value to the colonies in the New World which were crucial in the development of international trade. Trinidadian historian Eric Williams showed that the slave trade and slavery helped to make England the workshop of the world. Profit from slave-worked colonies and the slave trade were major sources of capital accumulation which helped finance the industrial revolution. The transportation of slaves transformed British seaport areas into booming centres.

While Europe invested profits from the trade in laying the foundation of a powerful economic empire, African kings and traders were content with wearing used caps and admiring themselves in worthless mirrors while swigging adulterated brandy bought with the freedom of their kinsmen. Virtually all the items imported during the nefarious business were for consumption or weapons 
for waging wars. Africa's contemporary history may have been different had its rulers and traders demanded capital goods for use in building the economy rather than trinkets, gin and booze. As it was, the slave trade arrested economic development in Africa. The loss in human resources had dire consequences for labour dependent agricultural economies. Any possibility that the internal dynamics of African society could have led to the development of capitalism and industrialisation was blocked by the slave trade. The few existing manufacturing activities were either destroyed or denied conditions for growth. Cheap European textiles, for instance, undermined local cloth production. The predominance of the slave trade also prevented the emergence of business classes that could have spearheaded the internal exploitation of the resources of their societies. The slave trade drew African societies into the international economy but as fodder for western economic development.

The Atlantic Slave Trade had enormous negative effects on the continent of Africa. Many parts of Africa suffered from an increase in violence, drain of people, and an economy increasingly reliant on slavery. Over four hundred years of slave trade had transformed the African Continent from coastal regions (where most of the trading with Europeans took place) all the way to the interior of Africa (where many slaves were captured to be sold.)

This was the earliest phase of European capitalist incursions into Africa. It occurred simultaneously with the epoch in western capitalist development called 'primitive accumulation'. ${ }^{15}$ At this time the West was breaking free from feudalism but had not yet entered the era of capitalism. According to Hopkins,

In three centuries before the industrial revolution the focus of the trade moved from the Mediterranean to the Atlantic, from Venice and Genoa to Liverpool and Nantes. This momentous shift of economic power was the product of fundamental changes in the economic and technological basis of European society at the close of the Middle Ages. ${ }^{16}$

The boost in trade increased the wealth of merchants and enhanced their power. Population decapitalization and anarchic plunder of Africa by western powers therefore corresponds to this era of mercantilism in Europe - a period which set the stage for the eventual collapse of feudalism. 
The West used unprecedented barbarism in their penetration, domination and pillage of African society. The purpose then was not to rule or govern; the purpose was unrestrained loot and plunder without parallel in Africa's history. The most horrendous form of it lasted from the fifteenth century to early eighteenth century. ${ }^{17}$ According to Marx, the history of this period is written in the annals of mankind in 'letters of wood and fire'. ${ }^{18}$ It was characterized by 'the turning of Africa into a warren for the commercial hunting of black skins'. ${ }^{19}$

The effects of this period in Africa can be briefly summarized as follows:

a. massive depletion of the African population, especially among the most relevant and productive groups;

b. massive destruction of the entire fabric of African society disruptions in socio-cultural relationships and, above all, the diversion of interest from productive activities to plunder and loot as a way of life;

c. the pillage of the resources of Africa under the guise of international trade. ${ }^{20}$

According to Hopkins, 'The chief effect of the overseas slave trade in the New World was to depopulate (Africa) and develop the abundant land resources of the Americas and the West Indies'. He further observes:

It remains true that the slave and sugar trades brought great wealth to the principal entrepots, such as Liverpool and Nantes, and to many other leading cities. It is impossible to account for the economic vitality of these parts in the eighteenth century, their physical and demographic expansion, and the remarkable overflow of money into cultural activities, without stressing the causative, though not exclusive, role of the Atlantic commerce. ${ }^{21}$

\section{Colonial imperialism}

European colonialism in Africa proved to be: (a) a system of administration; (b) a process of exploitation; and (c) a production system often geared towards the creation of capitalist relations of domination-subordination and the economic and socio-cultural 
enhancement of the colonizer. This may be done by covert or overt, psychological, legal and military mechanisms. Colonialism inhibited the development of indigenous technology in Africa to a large extent. Colonial domination brought with it a shift into a cash crop economy and de-stabilized some of the existing processes of technical growth.

The dumping of European goods took place in Africa. African markets were flooded with cheap mass-produced textile, glass and iron products in the context of policies such as 'the scrap iron policy' of Britain. Indigenous manufacturing capability was deliberately undermined to facilitate European exports. Captive markets were created. There were deliberate laws aimed at African indigenous technological development. Among the first groups to feel the impact of the invaders' new laws and activities were the metallurgists. These included the blacksmiths who forged iron and the whitesmiths who worked with lighter metal such as tin. Blacksmiths were depended on as much by farmers, for implements, as by the aristocracy and the political elite. This system of internal self-reliance changed.

\section{Conquests}

The colonial conquest of Africa by Europe was a three-step process fueled by the highest degree of avarice. First, came the exploration. In 1799, following Mungo Park's visit to the Niger, Sir Joseph Banks, head of England's Association for Promoting the Discovery of the Interior Parts of Africa declared:

We have already, by Mr. Park's means opened a Gate into the Interior of Africa into which it is easy for every nation to enter and to extend its Commerce and Discovery from the West to the Eastern side of that immense continent.

The exploration of the Continent was no easy undertaking. Scores of explorers lost their lives because of diseases or unforgiving Africans. But the appeal of African riches was too strong and the potential dividends too enormous to keep other explorers at bay. Mungo Park, Rene Caille, Livingstone, Stanley, to name just a few, brought back to Europe information on African geography, and thus facilitated the exploitation and the conquest of Africa. The pattern was simple: first the region was explored, then missionaries were sent in, and 
finally an occupation force followed. By 1884, roughly a century after Mungo Park's first trip, various European powers had claims on various parts of Africa. In December 1884 a conference took place in Berlin to resolve European disputes over colonial expansion. The Berlin Conference averted European wars over colonial possessions. In Africa, however, it did not stop colonial expansion. In the last five years of the nineteenth century only the Sudan and Ethiopia stood unconquered. By 1900 with the exception of Ethiopia, the partitioning of Africa was complete.

Belgium's creation of the Congo Free State goes to the essence of the economic and political systems established in colonial Africa. Between 1885 and 1908, there were about five million victims of Leopold's personal rule, under a barbarous system of forced labour and systematic terror. Hochschild examines how, in the nineteenth century European drive for possessions in Africa, the moral rationalisation of the 'civilising' mission was used to justify colonialism. An example was the founding of Leopold's International African Association (IAA) in 1876, at a conference of famous explorers in Brussels. As its first secretary, King Leopold opened the conference thus: 'To open to civilisation the only part of our globe which it has not yet penetrated, to pierce the darkness which hangs over entire peoples, is, I dare say, a crusade worthy of this century of progress' (Hochschild 1998:44). The aim of the conference was proclaimed to be 'abolishing the [Arab] slave trade, establishing peace among the chiefs, and procuring them just and impartial arbitration'.

Contrast this with remarks Leopold made to his London minister on the explorer Henry Morton Stanley, hired by the IAA to explore the interior of the Congo: 'I'm sure if I quite openly charged Stanley with the task of taking possession in my name of some part of Africa, the English will stop me... So I think I'll just give Stanley some job of exploration which would offend no one, and will give us the bases and headquarters which we can take over later on' (ibid.:58).

Leopold felt squeezed out by the British and French Empires, and the rising power of Germany. He studied forms of colonialism from the Dutch East Indies, to the British possessions in India and Africa. Leopold argued that forced labour was 'the only way to civilise and uplift these indolent and corrupt peoples of the Far East' (ibid.:37). 
Opposing the prevailing desire of Belgian parliamentarians to avoid the expense of colonies, he argued, 'Belgium doesn't exploit the world... It's a taste we have got to make her learn' (ibid.:38).

The King sent instructions to Stanley to 'purchase as much land as you will be able to obtain, and that you should place successively under... suzerainty... as soon as possible and without losing one minute, all the chiefs from the mouth of the Congo to the Stanley falls...' (ibid. :70). He was to purchase all the available ivory and establish barriers and tolls on the roads he opened up. Land rights treaties should be as 'brief as possible and in a couple of articles must grant us everything' (ibid.:71). Stanley secured 450 such agreements. Leopold developed a military dictatorship over a country 76 times the size of Belgium, with only a small number of white officials. Initially, he paid mercenaries, but in 1888 these were transformed into the Force Publique. At its peak, there were 19,000 conscripted African soldiers and 420 white officers.

By means of bribes and lobbying, Leopold gained recognition for the Congo in 1884 by the United States, followed by a similar deal with France. By making a web of bilateral agreements at the Berlin conference in February 1885, he carved out the boundaries for this huge state. Once his ownership of the Congo was secure, the rubber boom erupted. Joint ventures ensued between Belgian, British and Dutch firms. The profits saved Leopold's colonial empire. Apart from financing Leopold's private army and the Force Publique (which took up half the Congo's budget) to control the slave labourers who gathered the rubber, capital outlay was non-existent.

The Force Publique had a combined counter-insurgency role: as a force to suppress the natives and as a 'corporate labour force'. Their murderous assaults against the native population were described as 'pacification'. The demand was for labour, and they destroyed all obstacles in their way. Hochschild quotes the Governor of the Equatorial District of the Congo Free State when the demand for rubber became ferocious: "'As soon as it was a question of rubber, I wrote to the government, 'To gather rubber in the district... one must cut off hands, noses and ears"، (ibid.:165).

Towards the end of his rule, Leopold, desperate to stop the flow of information about the Congo getting back to the West, filed a libel suit against the black American missionary William Sheppard. 
Emile Vandervelde, a socialist lawyer and president of the Second International, went to the Congo to defend Sheppard; he made a brilliant defence speech and the publicity forced Leopold to retreat. Leopold attempted to destroy the evidence: for eight days in 1908 furnaces in Leopold's Brussels headquarters were at full blast, as Congo state archives were tuned to ash. He sent word to his agent in the Congo to do likewise. This, the 'politics of forgetting', was followed by the entire Belgian state.

More important were the limitations of the Congo Reform Association (CRA). The campaign effectively folded after the Belgian government took over the colony in 1908, as though the issues were resolved. Yet most of the brutal state officials deployed under King Leopold were retained by the Belgian state. With the profits extracted from the Congo, huge sums in compensation were paid to the king by parliament. Whilst the policy of holding women and children hostage or burning villages ended, the Belgians continued to use forced labour. Joint imperialist ventures in the Congo all utilised the Force Publique, while the French, German and Portuguese used the example of King Leopold's Congo as a template for their own systems of rubber extraction. It was safe for campaigners to single out the Congo because such outrage 'did not involve British or American misdeeds, nor did it entail the diplomatic, trade or military consequences of taking on a major power like France or Germany' (ibid.:282).

The second phase of Western domination of Africa corresponds to a definite historical epoch in European political economy. Marx observes that, driven by its internal dynamics, capitalism must 'nestle everywhere'. Having fought their national rivals, and having thus established their predominant position in the national economy, capitalists now shifted the theatre for profit and power to the international level known as imperialism. Lenin characterized imperialism as the last, monopoly, stage of capitalism, and identified five characteristic features of this phase of capitalism:

the concentration of production and capital developing to such a high stage as to create monopolies with a decisive role in the political economy; the merging of bank capital with industrial capital, forming finance capital and a financial oligarchy; the export of capital becoming more important than the export of commodities; 
the formation of international capitalist monopolies, which shared the world among themselves; and the completion of the territorial division of the world between the monopolies. ${ }^{22}$

Lenin, however, saw imperialism as an open-ended phenomenon with a discernible beginning but not necessarily an end. Historically, this phase corresponds roughly with the abolition of slave trade by Britain, in 1807, till the end of the century, when colonial governments were being established. This was the period of the industrial revolution in Europe. In the frantic search for cheap materials for its industrial production and captive markets for its products, European capitalist countries began occupying lands and setting up governments. Therefore, while imperialism was the monopoly stage of capitalism in Europe, for Africa it represented the beginning of an epoch when capitalism's first serious attempt was made to create conditions favorable for a more permanent implantation.

The principal actors were Britain, France and Germany, essentially acting through their chartered companies. In the scramble for a place in the 'colonial sun', large chunks of African hinterland were seized and claimed and counter-claimed by contending European firms. They could well have driven Europe to war for the sake of their illbegotten possessions.

A European Conference at Berlin was held to avert a military clash over colonial territories. Called at the initiative of the German government under Bismarck, it was attended by all the major European powers, including the United States which for the first time was participating in a major international conference with European powers. The European governments met to discuss ways and means of controlling the activities of their merchants before the latter plunged all of them into a bloody shooting war. ${ }^{23}$

The Berlin Conference resolved the conflicting territorial claims of these firms by making it obligatory for them to respect the territorial ownership if a trade or protectorate treaty had been signed with the African chiefs. More importantly, it worked out a general alliance between the imperialist powers for the balkanization and control of Africa. However, like all such alliances, the Berlin Conference agreement later turned out to be nothing more than a temporary truce which was destined to crack. ${ }^{24}$

Relations between the powers continued to deteriorate and, 
according to Allan Burns, the continued French incursion into the British 'territory' heightened the tension between them to the point where 'even war between France and Britain was not far from the minds of the cabinets'. ${ }^{25}$ The Conference thus heralded the continuation of the territorial struggle for control of raw materials and markets, even though the struggle was being conducted with the open and overt political support of their home governments.

\section{Colonialism}

This was the era of European monopoly capitalism in Africa. It was a stage in the development of industrial capitalism in Europe dominated by giant corporations, each of which sought to control a relatively high proportion of the local or African markets for its products. This means that instead of simple price competition between small independent producers, there was greater importance for finance and investment. Competition between large corporations each with monopoly control in different areas of Africa took the form of competition for finance, for sources of raw materials and for profitable investment opportunities.

European presence implied a fundamental change in the concept of power, a profound alteration in the culture, and welfare of whole populations. Cash crops were emphasized to the detriment of existing African economy. The view of Africans became even more deprecatory than during the height of the slave trade. Colonialism made a point to accentuate perceived African inferiority and the adoption of imported paradigms anesthetized African Power. Colonialism prevented African leadership from exercising even the feeblest control over the accelerating changes.

This phase of capitalist domination in Africa, in the form of colonialism, corresponds to the period between the beginning and middle of the nineteenth century, when colonialism was institutionalized in most seized lands. Colonialism was a unique form of capitalist domination and control which had not existed earlier. The uniqueness consisted in its totality. It was the most complete and the most direct form of Western domination. It was the most comprehensive strategy of capitalist penetration, domination and control because it left no facet of society untouched. ${ }^{26}$ 
Above all, it involved direct political and military administration of people to effect sustained maximum economic exploitation, through an organized, disciplined and, above all, administered capitalism in Africa. Colonialism became the politico-military weapon for effective and institutionalized administration of the territories their companies had earlier 'acquired'. Colonialism aimed at creating both international and internal order and discipline from an otherwise anarchic imperialist system by means of direct imposition of superior military-political power.

The imperialist system collapsed for a number of reasons:

1. an increasing inter-European counter-penetration of the areas;

2. an increasing African recalcitrance, resistance and hostility to further European penetration and control;

3. the rising cost and complexities of administering Africans far beyond what the companies could 'profitably' continue to undertake.

Colonialism attempted to remedy this by:

- $\quad$ lending some sort of international credence and/or legitimacy to the ownership of the areas concerned;

- $\quad$ gaining better internal control of the African through their acquiescence or passivity;

- $\quad$ providing political clout to facilitate the creation of a more efficient system of exploitation to foot the cost of policing the people.

Therefore colonial imperialism truly was beginning of the monopoly stage of capitalism in Africa. The institutionalization of the metropolitan power over African territories gave it the rationale of keeping other rival powers from its territory and preventing the intrusion of other competing monopoly firms.

In the process, the laissez faire and free trade of the political economy of Adam Smith, which had ruled Europe from the early phases of industrial capitalism, were thrown overboard. ${ }^{27}$ The Berlin Conference had reiterated the principle of free trade and put the signatory powers, 
under obligation to adhere to the principles of free trade by allowing other nationals free access to the area and to protect foreign merchants and all trading nationalities as if they were her own subjects. ${ }^{28}$

The repudiation of the principle signified the death of free trade in the international market and legitimized monopolies at both ends in Europe as well as in Africa. This distinction between colonialism and the earlier phase of imperialism should not be overlooked. During imperialism, the monopolies' right to territorial exclusivity was recognized neither by their home governments nor by the international community, making it very difficult for companies of one nation to exclude those of others, since they could not count on the official support of their home governments. ${ }^{29}$

The decline of colonial imperialism was fast - indeed, faster than anything the West had imagined. ${ }^{30}$ Colonialism was a very unstable system, marked by uncertainty and fear and maintained by violence and brute force. It was a situation in which both the settlers and the natives had lived, according to Fanon,

In keeping with the rules of pure Aristotelian logic, they both follow the principles of reciprocal exclusivity. The settlers' town is a strongly built town, all made of stone and steel. It is a brightly lit town, the streets are covered with asphalt and the garbage cans swallow all the leavings. The settlers' feet are never visible except perhaps in the sea, but there you are never close enough to see them. The settlers' town is a well-fed town... its belly is always full of good things. The settlers' town is a town of white people, of foreigners. ${ }^{31}$

On the other hand, the town belonging to the natives was:

a place of ill fame, peopled by men of ill repute. They are born there, it matters little where or how; they die there, it matters little where or how. It is a world without spaciousness. The native town is a hungry town starved of bread, meat, of shoes, of light. It is a town of niggers and dirty Arabs. ${ }^{32}$

\section{Birthing Pan-Africanism}

Pan-Africanism was a gift of the new world of America to the old world of Africa. 'Pan-Africanism was born', in the words of Diallo 
Telli, 'in the emotional atmosphere of complete alienation, physical exploitations, and spiritual torment. When Henry Sylvester-Williams of Trinidad convened a Pan-African conference in 1900, he did this largely to mobilize solidarity for Africans threatened in various ways by depredations of colonizers in various parts of the continent' (see Wallerstein 1967:7).

The conference was held in the wake of the Boer War and of Rhodes's expansion in Central Africa. The conference also resulted from the enactment of the Jim Crow laws in the southern United States. At that time, racism was a respectable doctrine, popular even in the universities. To the new sentiment of racial self-assertion and solidarity, the term 'Pan-African' was applied; W.E.B. DuBois proclaimed at this conference that 'The problem of the twentieth century is the problem of the color line' (Wallerstein 1967:7). This sense of racial solidarity began soon after to take organizational forms. In the United States, there was the Niagara movement of 1905, followed by the creation of the National Association for the Advancement of Colored People in 1910. In South Africa the African National Congress was founded in 1910. In West Africa, the first contacts were made which led to the convening in 1920 of the National Congress of British West Africa. In Senegal, Africans assumed a leading role in the politics of the commune of Dakar, and the first deputy was elected in 1914.

In all of these cases the social composition of the new organizations was the same. They were made up of relatively well-educated, relatively well-off African (or Afro-American) professional and business men. All of their programmes were dedicated to achieving equal rights and increased educational opportunities, and to the assertion of the validity of the African cultural heritage. Their programme was the programme of western liberalism. As DuBois said in The World and Africa, 'their plans had in them nothing spectacular nor revolutionary' (Wallerstein 1967: 8).

In 1917, the Russian Revolution occurred. Thus in a major European country, a group of men came to power, whose doctrine was far from the liberal egalitarian ideals of the Pan-Africanist. The Pan-Africanists were African and Afro-American intellectuals who had to some degree dedicated themselves to a class analysis of many of the problems of race. 
Protest based on race had come to terms with protest based on class, especially since the latter seemed relatively more successful, certainly intellectually more sure of itself, and commanded more mass support. The intellectual impact was slow rather than sudden. In time Marxists' hypotheses came to permeate the thinking of African intellectuals, who began to see colonial and racial oppression as based on economic considerations. Ironically, this slow assimilation of class analysis served to integrate these intellectuals in the White world. Richard Wright reveals the following point:

The fear inspired by White domination breeds a tendency... to make Asians and Africans act, pretend. This same almost unconscious tendency to pretension will spur them to pretend to accept an ideology in which they do not believe. They accept it in order to climb out of their prisons. Many a Black boy in America has seized upon the rungs of the red ladder to climb out of his Black Belt. And well he may, if there are no other ways out of it. Hence ideology becomes a means toward a social intimacy.

There were two quite separate lessons symbolized by the Russian Revolution. One was a way of analyzing the world. The other was a way of changing it by organized, militant, mass action. It was possible to absorb one lesson without absorbing the other. Most of the intellectual leaders of African and Pan-African movements of this time really learned only the first lesson. They were in this sense armchair revolutionaries. The leader of the black world who learned the second lesson best was, paradoxically, one of the few who rejected the theories of communism outright. He was Marcus Garvey.

Marcus Garvey was a Pan-African Nationalist: For him Africa was the ancestral home and the spiritual cradle of all African-descended people. His paramount political goal was to wrest the continent from the tyrannous European imperialist grasp and build a free, united, black Africa. This was to be achieved by the planned repatriation of a revolutionary vanguard of new world blacks in cooperation with like-minded Africans. The Marcus Garvey movement of the 1920s became one of the most phenomenal social movements in modern history, and his name one of the best known both within and outside the Black world. Garvey did not succeed in his specific goals, but the memory of the man and his movement remained a powerful 
source of inspiration to black Nationalists, both in the new world and Africa (Jacques-Garvey, 1970:2).

There were two main circuits of discourse for African and BlackAmerican intellectuals in the period between the two world wars. The first centred around the leadership of W.E.B. DuBois. DuBois had been active in the Pan-African Conference of 1900. After the First World War, he convened in 1919 in Paris a Pan-African Congress with the aim of influencing those who were drafting the peace treaties. The first congress was followed by a second in 1921 in London, Paris and Brussels, a third in 1923, in London and Lisbon, and a fourth in New York in 1927. All these congresses were dominated by Western Hemisphere blacks and the organizers had a difficult time establishing rapport with major African groups.

These congresses petered out, partly because the impact of the depression cut off financial support. In 1935, a number of former participants in the congresses plus a Gold Coast group that had been created in 1934 came together. These groups organized to protest certain colonial legislation and formed the International African Service Bureau, which emerged in 1944, with a number of African groups, largely in England, into the Pan-African Federation. It was this group which convened the Fifth Pan-African Congress in Manchester in 1945, and called on DuBois to preside over it.

Among this group, a flame was preserved. This flame saw an intellectual tradition that was influenced by Marxism, but never subordinate to it. This group was concerned primarily with the rights of black people. Increasingly, however, it concentrated on purely African problems, first land rights, later political emancipation in general. It always saw the relevance of the wider struggle of the colonial people and the need for alliances with progressive white forces, but remained nonetheless primarily a black Pan-African movement.

The demand for independence was thus being prepared on the intellectual plane at least as early as the 1920s; the African revolutions of the 1960s erupted only after a slow evolution (Kesteloot 1927:1314). Political action followed logically from the idea of the cultural commitment of the intellectuals.

The second major circuit of discourse was located in the French literary world. Here in the mind-set of European civilization was a group of harsh critics who sought to answer the discretions of a 
rationalized, industrial society by an appeal to the senses, to a renewal of so-called primitive visions. Denouncing bourgeois capitalist society, racism, and the ethnocentrism of Europe, they could not fail to find a sympathetic audience. Indeed there were disciples, among the African and Caribbean intellectuals in Paris and in the French world, men such as Leon Damas, Etienne Leto, and later, Aimé Césaire. The group of Carribean students in 1932 founded the journal Legitime Defense and accepted surrealism unreservedly as its basis.

The two circuits were not entirely separate. They were linked by a perhaps unexpected group, the American authors of the Negro Renaissance, such as Claude MacKay, Langston Hughes and Countee Culeen. Produced by the new American black intellectual world so deeply influenced by DuBois, they followed the path of American white authors attracted to Paris in the 1920s. They sought human freedom in artistic freedom and in throwing off constraints of traditional forms. In this period, American Negro, Caribbean and French African writers rediscovered Africa together.

The imposition of colonial rule on the continent put Africans from every walk in life in a position of powerlessness. Colonial rule was alternately direct or indirect. In the regions where direct rule was applied traditional rulers were simply pushed aside and became irrelevant. In the other regions where indirect rule took effect, these traditional rulers turned into puppets: they were protected when they carried out colonial policy and removed from power when they became obstructionists. In addition to this powerlessness, Africans had to perform in a new culture and new institutions which accentuated their feelings and perceptions of inferiority. But before long, an African elite emerged. Some of this elite resented the colonial presence and started agitating for change. The most renowned proponent of African liberation in the nineteenth century was Edward Wilmot Blyden. Blyden was born in 1832 in the Virgin Islands. After studying in the United States, he settled in Liberia in 1850. He took upon himself the task of developing a philosophy that would unite Africans and compel them to challenge their secondclass status in the world.

Blyden had a profound impact on the African intellectual elite of the nineteenth century. He was the first to speak of an 'African personality'. He essentially stirred Africans towards independence 
and self-sufficiency, urging them 'not to suppose that the AngloSaxon methods are final'. Notwithstanding Blyden's influence, European political rule imposed itself by force and succeeded to stifle voices of dissent on the continent so well that the main activity for African liberation took place outside the African continent. Two organizations deserve special mention: the Black Zionist Movement and the Pan-African Movement.

The Black Zionist Movement was the creation of Marcus Garvey, a Jamaican. Based in New York, it urged the Diaspora to return to Africa to build a new state and civilization. The movement galvanized millions of Diasporan Africans. The Black Zionist Movement collapsed in 1925 with the deportation of Marcus Garvey. The PanAfrican Movement was the creation of another West Indian, Henry Sylvester-Williams. He organized a mini-Pan-African Conference in London in 1900. But it took the creative genius of W.E.B. DuBois to build Pan-Africanism into a force to reckon with.

Under the leadership of DuBois the ideals of Pan-Africanism inspired many Africans and Diasporan Africans. The fifth PanAfrican Congress proved decisive. Among the organizers were Kwame Nkrumah and Jomo Kenyatta. Nkrumah was rapporteur of two sessions when West African colonies were discussed. Nkrumah would later put into practice the resolutions of the PanAfrican Congress when he returned to his native Gold Coast. These ideas ultimately led to the independence of Ghana in March 1957. Nkrumah saw Ghana's independence as the first step in a revolutionary process.

Slowly an intellectual attitude was evolving, which was the major achievement of the intellectuals in the years between the wars. Meanwhile, some of the Pan-African intellectuals tried to find an organizational base in the world communist movement. George Padmore was active in the Black Bureau of the Profintern, the tradeunion adjunct of the Comintern. Padmore encountered what he called the eroding influence of doctrinaire Marxism, including the curious Soviet pressure to support Black states within the United States and the union of South Africa, and thus they took their distance from the communist movement. (Wallerstein 1967:11). For all these reasons, as the Second World War approached, the results of their efforts were meager. A French colonial administrator, Henri Labouret, writing 
in 1937; 'At the present times the Pan-Negro movement born in the new world scarcely seems to menace the White hegemonies in Africa' (quoted in ibid.:12-13).

In the period following the Second World War, from 1945 to 1957, the Pan-African movement became far more visible to the rest of the world, and indeed to Africa itself. In 1945, the Fifth PanAfrican Congress was convened in Manchester and presided over by DuBois. The delegates still came overwhelmingly from the Englishspeaking world, but for the first time Africans like Kwame Nkrumah, Wallace Johnson, and Jomo Kenyatta were at least prominent. Antiimperialism and anti-colonialism became the major themes of the congress, and also for the first time, national independence was openly asserted to be the only valid solution to Africa's political aspirations (Wallerstein 1967: 13).

Meanwhile, the Paris circuit continued on its largely separate way. There was some contact between Nkrumah and various French West African leaders such as Houphouet-Boigny, Senghor, and Apity in 1946. For the time being, Pan-Africanism for the French Africans remained a cultural ideal, as French colonial policy ruled out political devolution of power as unthinkable. French cultural policy created far greater pressure on African intellectuals than did British, and consequently evoked a greater reaction. Thus, the French-speaking Black intellectuals in Paris evolved the doctrine of Negritude. The journal Presence Africaine, founded by Alioune Diop, became the focal point of this movement. The tradition of contact with the French intellectual world was maintained by the participation in a Comité de Patronage of the journal with such figures as Sartre, Gide, Camus, and Mounier. The tradition of contact with the black American literary world was maintained by the close collabouration with such later exiles as Richard Wright. The tradition of contact with the communist world was also maintained, notably by the membership in the French communist party of Césaire, who was for many years elected a member of the French National Assembly from Martinique on the communist party's ticket.

In 1955, however, Presence Africaine discreetly dropped its European Comité de Patronage. The following year Césaire sent a letter to Maurice Thorez, in which he resigned from the French communist party. He explained: 
One fact of primary importance to me is this: That we men of color, in this precise moment of historical evolution, have, in our consciousness, taken possession of the whole domain of our particularity and then we are ready at all levels and in all matters to assume the responsibilities which devolve from this new consciousness. What I want is that Marxism and communism be placed at the service of Black people and not Black people at the service of Marxism and communism (Wallerstein 1967:14).

In September 1956, Presence Africaine convened the first World Congress of Black Writers and Artists, which was able to get significant participation from the English-speaking Black world even though it was an outgrowth of the Paris Pan-African circuit. The gap was beginning to close between the two linguistic-social worlds into which Black men had been divided. Alioune Diop summed up most aptly in his opening address the key proposition which was to pervade and justify this most important cultural event in the history of the Pan-African movement:

It is important to point out here that all of us, whether we believe in God or are atheists, whether Christians, Moslems, or communists, have in common the feeling of being frustrated by western culture. To which Cesaire added: There are two ways to lose oneself: Segregation within the walls of the particular or by dilution in the universal. My conception of the universal is that of a universal rich with the particular, rich with all the particulars, a deepening and a coexistence of the particulars (Wallerstein 1967:15).

\section{Killing Pan-Africanism}

Pan-Africanism promoted the nationalisms that gave Africa independence in the 1960s. However, the establishment of the PanAfricanist ideal remains essentially unfinished. An organization whose acclaimed objective was to unify Africans was created in the 1960s but forces that benefit from African divisions rose up and made their best attempt to weaken this organization. In its first incarnation on the continent, the Pan-African ideal fared very poorly in its execution. Two groups were formed: a progressive group, led by Ghana that was named the Casablanca movement, and a more conservative group known as the Monrovia group. The ensuing 
charter of the OAU reflects the conservative group and its lack of vision and imagination.

A weak Organization of African Unity made the task of the enemies of Africa easy. Moreover, in the euphoria that followed the independences, Africans never sat down to evaluate the institutions they were inheriting from colonialism. Were these institutions designed with the interest and the well-being of Africans in mind? There were plenty of legitimate questions that deserved to be answered. Was the colonial justice suitable for an independent African nation? Did it best serve the interests of the African people? Nobody asked these questions. What type of education would best realize the economic objectives of an independent African nation? What type of mode of production would accelerate African development?

Since Africans were not operating in a vacuum, but with a background of thousands of years of civilization, the right thing to do was to place these imported paradigms alongside genuine African institutions, compare them, extract values in each of them and if possible adopt some of these values and reject others. And above all, the African people were to be consulted. Unfortunately the people had no say in the adoption of these colonial institutions.

The African army, inherited from colonial rule, was one of the institutions that needed to be scrutinized after the independences. The colonial army was essentially an anti-African institution used essentially to vigorously suppress dissent. It was responsible for the death of millions of Africans. It was not an army designed to protect territorial integrity and defend the populations. It was an army designed to protect the status quo. With pernicious effect, this army essentially started to exact its toll. Coups d'etat soon gained currency. By 1989 more than 60 coups d'etat had been committed by African armies. The dictatorships that ensued brought havoc to many African regions. In many instances, it was the age of the indirect rule again. This time around the traditional rulers were replaced by military dictators, while former colonial powers went on their business of spoliation. 


\section{Neo-colonialism}

Neo-colonialism appeared on the African scene in the decade following World War II. Its predecessor, colonialism, was destroyed by two convergent pressures: one internal and the other external. Internally, the Pan-Africanist/nationalist sentiments, whipped up in the course of the West's mobilization of African manpower and resources to fight Nazism, turned against their European masters. Africans were determined to wrest power from them. ${ }^{32}$

Externally, besides world opinion being against colonial domination, the West feared communism becoming an attractive alternative to the colonized. The colonial powers accepted the inevitability of retreat, but cleverly turned it into a tactical withdrawal, giving up the form of domination but retaining its substance. Foreign faces were withdrawn from positions of power, but only after their places had been taken by hand-picked native faces ('interlocuteurs valables' -negotiators worth talking to ${ }^{33}$ ). Exploitation continued unabated, the grip remained as tight, the control of the 'new independent nation' was total, but the system was so sophisticated that it functioned by 'remote control' without the irritating physical presence of the colonialist.

The defining features of this neo-colonialism, which lasted for about a decade after the attainment of formal independence, were:

- that the former colonial master still served as the exclusive reference group for the new nation;

- that the former ruler still exercised domination over every aspect of life: political, economic, and cultural. We shall consider them briefly below.

\section{Political domination}

The new nations emerged out of colonialism usually with constitutions that were drafted at the metropolitan headquarters. The essential government and its political institutions - e.g. the executive, the legislature, the judiciary, and political parties - were modeled on those obtaining in the former ruling nations. In the international arena, it was the former colonial power which chaperoned the representatives of the new nation through the diplomatic corridors and put them through the paces in diplomatic etiquette - the first 
principle of which, not unsurprisingly, was that they must endorse the foreign policy of the metropolitan power. The army and other security forces of the new nation were still trained and manned by the former masters who guaranteed the protege's national and international security. This was economically and politically very beneficial to withdrawing colonialists.

African states today are not, in any real sense, capitalist states. Elsewhere, the state has played a crucial role in facilitating capitalist expansion, but in postcolonial Africa one finds a form of neopatrimonialism - personal rule - that introduces a variety of economic irrationalities. Productive economic activities are impeded by the political instability, systemic corruption and maladminstration associated with personal rule. In extreme cases, a downward spiral of political-economic decline is set in motion that is difficult to halt and reverse. Thus, personal rule has become simply a euphemism for ineptitude and mismanagement that operates according to a particular political rationality that shapes a ruler's actions when, in the absence of legitimate authority, he is confronted with the challenge of governing an unintegrated ethnically-diversed peasant society. Neopatrimonialism is essentially an adaptation of colonialinspired political institutions to peculiar historical and social conditions of poverty and inequality.

African rulers and their actions serve specific interests. The failure of democracy and economic development in Africa are due largely to the scramble for wealth by predator elites who have dominated African politics since independence. They see the state as an arena for personal wealth accumulation. There is high premium on the control of the state, which is the biggest and most easily accessible source of wealth accumulation. The people in power and those who seek power use all means to attain their goal of capturing the state. The strategies for capturing include fostering ethnic sectarianism and political repression. Competition for control of the state, whether between the military and civilian classes or between civilian political parties, is invariably ferocious and generates instability. Many of the apparently senseless civil conflicts in Africa are due to the battle for the spoils of power.

Franz Fanon (1961) eloquently described the character of the class that inherited power from the colonialists. It is 'a sort of little 
greedy caste, avid and voracious, with the mind of a huckster, only too glad to accept the dividends that the former colonial power hands out. This get-rich-quick middle class shows itself incapable of great ideas or of inventiveness. It remembers what it has read in European textbooks and imperceptibly it becomes not even the replica of Europe, but its caricature'. This class is not capable of building industries: 'it is completely canalised into activities of the intermediary type. Its innermost vocation seems to be to keep in the running and to be part of the racket. The psychology of the national bourgeoisie is that of a businessman, not that of a captain of industry'. The description remains valid today for Africa's predatory elite who have grown through civilian politics, military governments, business and the civil service.

As long as African political rulers and administrators are drawn from this class of parasites, no amount of preaching the virtues of good governance or tuition on public administration will fundamentally alter the quality of governance. This is not to say that constitutional reforms and increasing civil society infrastructure are not important. But they are not the key to solving the problem of bad governance.

Good governance is the effective exercise of power and authority by government in a manner that serves to improve the quality of life of the populous. This includes using state power to create a society in which the full development of individuals and of their capacity to control their lives is possible. A ruling class that sees the state solely as a means of expropriating the nation's limited resources is simply incapable of good governance. More specifically, such a class will, by its character and mission, abuse power due to its lawlessness.

An underlying cause of many of the manifestations of bad governance, including political repression, corruption and ethnic sectarianism, is the endeavour by the unruly ruling classes to be and remain part of the global elite despite their nation's poverty. The competition for national resources leads to conflict and repression. It is difficult to see how there can be good governance when the orientation of the elite is to stay in the running and be part of the fifth of the world's population that forms the international consumer class.

Bad governance is not mainly a problem of ignorance or lack of infrastructural capacity or even of individual dictators. States in Africa are incapacitated as instruments of development because ruling 
classes, including people in and outside government, are motivated by objectives that have little to do with the common good.

Africa's tragedy is not that its nations are poor. The tragedy is that it lacks ruling classes that are committed to overcoming the state of poverty. Real politics here has little to do with social and economic reconstruction. The observation of the South African writer Ruth First (1970) remains valid today: 'There has been eloquent, inexhaustible talk in Africa about politics, side by side with the gaping poverty of political thought. Down there on the ground in Africa, you can smother in the small talk of politics. Mostly it is about politicking, rarely about policies. Politicians are men who compete with each other for power, not men who use power to confront their country's problems.'

As long as politics is dominated by predator elites it is difficult to see how meaningful democracy or economic development can be sustained. The challenge facing those who want better governance is how to make those in power accountable and ultimately rescue the state from them to transform it into an agency for positive change.

\section{Economic domination}

Over the past few decades, much of the world focused on the debt crisis of Latin America. But the economic crisis in Africa was one that was more complex and rested on issues deeper than the shortterm financial obligations of Latin American countries. The woes of the African economy were plentiful. Agricultural production, governmental institutions, and political origins were only a few of the contributors to the economic crisis of this vast continent. Besides, the pattern or monopoly domination of the colonial era still operated exactly in tact. The foreign exchange reserves of the new nations were still kept in the metropolitan headquarters. A large part of the foreign trade of the new nation was still with the metropolitan country.

Agricultural production has long been the primary export of African countries. However, Africa's population rapidly increased with the increase in agricultural production. Although Africa is largely agricultural, the continent had to import increasing amounts of food to keep pace with the population growth. During the 1960 s, agricultural production increased at a rate of 2.3 percent greater than the population increase. By the 1970s, increase in 
agricultural products slowed, while population accelerated and in some years Africa was just barely breaking even. In two countries, food production was actually less than the population increase and accounted for the need of imports.

Another agricultural problem persisted in the farmlands. Farming in much of Africa was based on a system where land was cleared, cultivated for several years, and left fallow to gain its fertility. However, the pressure exerted by a rapidly rising population forced farmers to shorten necessary fallow periods, thus decreasing the fertility of the land. In the long run, farmers paid the price of declining soil productivity and mounting weed and pest problems. To overcome such difficulties caused by continuous cultivation, Africa's farmers would need better seeds and fertilizers, pesticides, and technical aids, but all of these things are very expensive for lowlevel subsistence farmers.

The agricultural problems of Africa did not stop at the population increase or the farmlands, but continued to incorporate an irrigation crisis. African farms depended heavily on rainfall in an area frequented by droughts. Africa has a number of major river systems that could potentially serve as sources of irrigation, but constructing and maintaining irrigation facilities is expensive. Finally, two pests accidentally imported from the Western hemisphere threatened the production of Africa's staple crop. Africa's major export, agricultural goods, was definitely in trouble from every viewpoint imaginable.

The foundations for the economic ailments had already been laid in the 1970s and 1980s. State enterprises inherited from colonial powers ran the national airlines, public utilities, large-scale agricultural products, and financial institutions. These enterprises also regulated the sale and price of many commodities. The presence of the government in the economy was substantial and in socialist-oriented countries, these enterprises were hostile to private investment. These governments were subject to political influence and pressures and when they failed to operate efficiently, they became a financial drain on the government and were replaced with a new group of leaders.

African leaders soon replaced the political institutions and the new leaders attempted to monopolize their power. National economic resources and policies became a political battleground. 
Political leaders sought to enhance national pride, but more so, their own positions, by spending money on prestigious projects. These new buildings were visible, but expensive and unproductive from an economic viewpoint. Government agencies became sources of employment of supporters of the party in power and selected and located investment projects on political rather than economic grounds. In many countries, politicians created lavish lifestyles financed by public resources. This allowed and possibly persuaded lower level public officials into corruption in order to supplement their inadequate incomes.

Another increasingly prominent factor in African politics was the military and its demands. The military was often motivated by a desire to improve its own circumstances. Enlarging arsenals, modernizing equipment, and raising salaries were top priorities. In 1970 , African countries spent $\$ 175$ million on importing arms; by 1979 , these estimates had skyrocketed to $\$ 2.3$ billion.

One suggestion of improving the situation in Africa was that of self-sufficiency. This requires the cooperation of all the countries to purchase goods and services from other countries of the continent. Although it is a good idea, it is difficult to maintain because it can hurt poorer countries. These countries are obliged to purchase goods from their wealthier partners over cheaper products from established industries in industrialized countries. This causes the poorer countries to feel that they do not share equally in the benefits of such economic unions.

\section{Cultural domination}

To ensure its exclusive domination in the cultural life of the colonized people, the colonial government hammered into them its own values, social norms and social organization. It assiduously inculcated in them the feeling that its own culture and education were superior to those of other Western nations. The indigenous culture the colonialist destroyed was supplanted, not by European culture as such, but by its own particular brand of European culture. Strong bonds of affection and shared values between the 'two' nations were emphasized. The function of media was to disseminate news about the former colonial ruler. 
The form and content of education were the same as in the erstwhile ruling nation. Students who got a chance to go overseas for further studies normally went to the metropolitan country. Until recently in Nigeria, for instance, if one studied outside Britain, one would be hard pressed to find a job back home. The neo-colonialism era was supposed to be a period of apprenticeship for the fledgling nation under the tutelage of the former ruler for graduation to full nationhood.

The process of colonization involves one nation or territory taking control of another nation or territory either through the use of force or by acquisition. As a by-product of colonization, the colonizing nation implements its own form of schooling within its colonies. The idea of assimilation is therefore important when dealing with colonial education. Assimilation involves those who are colonized being forced to conform to the cultures and traditions of the colonizers. Gauri Viswanathan points out that 'cultural assimilation (is)...the most effective form of political action' (Viswanthan 85). She continues: 'cultural domination works by consent and often precedes conquest by force'.

Colonizing governments realize that they gain strength not necessarily through physical control, but through mental control. This mental control is implemented through a central intellectual location, the school system. Kelly and Altbach (1984:2) state that 'colonial schools, sought to extend foreign domination and economic exploitation of the colony'. They find that 'education in...colonies seems directed at absorption into the metropole and not separate and dependent development of the colonized in their own society and culture' (ibid.:4). The process is an attempt to strip the colonized people away from their indigenous learning structures and draw them toward the structures of the colonizers.

Much of the reasoning that favors such a learning system comes from supremacist ideas of leader colonizers. Thomas B. Macaulay asserts his viewpoints about a British colony, India, in an early nineteenth century speech. Macaulay insists that he has 'never found one among them [Orientalists, an opposing political group] who could deny that a single shelf of a good European library was worth the whole native literature of India and Arabia'. He continues stating, 'It is, no exaggeration to say, that all the historical information which has been collected from all the books written in 
Sanscrit language is less valuable than what may be found in the most paltry abridgments used at preparatory schools in England'. The ultimate goal of colonial education might be deduced from the following statement by Macaulay: 'We must at present do our best to form a class who may be interpreters between us and the millions whom we govern; a class of persons, (African) in blood and colour, but English in taste, in opinions, in morals, and in intellect'. While all colonizers may not have shared Macaulay's lack of respect for the existing systems of the colonized, they do share the idea that education is important in facilitating the assimilation process.

Often, the implementation of a new education system leaves those who are colonized with a lack of identity and a limited sense of their past. The indigenous history and customs once practiced and observed slowly slip away. The colonized become hybrids of two vastly different cultural systems. Colonial education creates a blurring that makes it difficult to differentiate between the new, enforced ideas of the colonizers and the formerly accepted native practices. Ngugi Wa Thiong'o displays his anger toward the isolationist feelings colonial education causes. He asserts that the process 'annihilate(s) a people's belief in their names, in their languages, in their environment, in their heritage of struggle, in their unity, in their capacities and ultimately in themselves. It makes them see their past as one wasteland of non-achievement and it makes them want to distance themselves from that wasteland. It makes them want to identify with that which is furthest removed from themselves' (Ngugi 1981: 3).

Not only does colonial education eventually create a sense of wanting to disassociate with native heritage, but it affects the individual and the sense of self-confidence. Ngugi believes that 'education, far from giving people the confidence in their ability and capacities to overcome obstacles or to become masters of the laws governing external nature as human beings tends to make them feel their inadequacies and their ability to do anything about the condition of their lives'.

In order to eliminate the harmful, lasting effects of colonial education, post-colonial nations or territories must remove the sense of nothingness that is often present. Ngugi insists that 'To decolonize our minds we must not see our own experiences as little islands that are not connected with other processes' (ibid.). 
Post-colonial education must reverse the former reality of 'education as a means of mystifying knowledge and hence reality'. A new education structure boosts the identity of a liberated people and unites previously isolated individuals.

Kelly and Altbach (1984) define 'classical colonialism' as the process when one separate nation controls another separate nation. However, another form of colonization has been present in America for many years. The treatment of the Native Americans falls into the category of 'internal colonization', which can be described as the control of an independent group by another independent group of the same nation-state. Although the context of the situation is different, the intent of the 'colonizers' is identical. This includes the way in which the educational system is structured. Katherine Jensen indicates that 'the organization, curriculum, and language medium of these schools has aimed consistently at Americanizing the American Indian' (1984:155). She proceeds and asks, 'If education was intended to permit native people mobility into the mainstream, we must ask why in over three centuries it has been so remarkably unsuccessful' (ibid.:155).

\section{Deepening dependency}

This is critical and the latest phase of capitalist domination in Africa. While in the neo-colonialism period the former colonial master still held and exercised the dominating and unchallenged influence in the affairs of the new nation, dependency betokens a shift in the focus of attention till domination becomes truly 'international', the uninational monopoly control having been broken. It makes possible the expansion of the cultural area of the former colonies. ${ }^{34}$

The emotional debate over the impact of structural adjustment on the poor in Africa has been confused by the complexity of economic reforms and their inconsistent implementation, the diversity of prior conditions, and confounding effects of external shocks. The main instruments of implementing the policy of deepening Africa's dependence are assured by the Bretton Woods institutions, to ensure that debt repayment is done in such a way that social spending and development must be cut back and debt repayment must be made the priority. In effect, the International Monetary Fund and World 
Bank demand that these poor nations lower the standard of living of their people.

The IMF and World Bank prescribe cut backs, 'liberalization' of the economy and resource extraction/export-oriented open markets. Following an ideology labeled "neoliberalism" the role of the state is minimized. Structural adjustment programmes also encourage privatization and reduced protection of domestic industry. Other adjusment policies also include currency devaluation, increased interest rates, and the elimination of subsidies such as food subsidies. To be attractive to foreign investors various regulations and standards are reduced or removed. For poorer countries these impacts can be devastating. Factors such as the following lead to further misery for the developing nations and keep them dependent on developed nations:

- Poor countries must export more in order to raise enough money to pay off their debts in a timely manner.

- Because there are so many nations being asked or forced into the global market place - before they are economically and socially stable and ready - and told to concentrate on similar cash crops and commodities as others, it is like a huge price war.

- The resources then become even cheaper from the poorer regions (which favours consumers in the West).

- Governments then need to increase exports (by further reducing costs, making the resources even cheaper etc) just to keep their currencies stable (which may not be sustainable, either) and earn foreign exchange with which to help pay off debts.

- Governments therefore must spend less, reduce consumption, remove or decrease financial regulations, and so on.

- Over time then, the value of labour decreases, capital flows become more volatile, and we get into a spiralling race to the bottom. Social unrest is often one result.

- These nations are then told to peg their currencies to the dollar. But keeping the exchange rate stable is costly due to measures such as increased interest rates etc.

- Investors obviously concerned about their assets and interests can then pull out very easily if things get tough. In worst cases capital flight can lead to economic collapses like we have seen in 
the Asian/global financial crisis of 1997-99, Mexico, Brazil and many other places - of course, the blame by mainstream media and free trade economists is laid on emerging markets and their government's restrictive or inefficient policies, crony capitalism etc, which is a cruel irony.

- Keeping the exchange rates in their favor by IMF donors, means that the poor nations remain poor, or get even poorer. Even the 1997-99 global economic financial crisis around the world can be partly blamed on structural adjustment and overly aggressive and early deregulation for emerging economies.

Most African nations entered this phase of dependency domination in the 1970s - that is, a decade after their political independence. In this phase, the new nations are subjected to a diffused and complex system of control and exploitation in a situation created by the cumulative effects of the various phases of domination. The end product of this process is a retarded African political economy. Retarded in the sense that the political economy (not the economy) does not and cannot sustain an independent existence. The negative forces have acquired a dynamic of their own and serve to ensure the continued development of underdevelopment in Africa.

Dependency domination is the capitalist strategy of control and exploitation in the modern system where international financial organizations and multinational companies have become vital actors; together they have perfected an intricate and complex control network on which the African nations, as all Third World nations, are hooked. The control mechanisms have been institutionalized, and they have acquired legitimacy within the international system. It is therefore much more difficult to try to break away from the syndrome because it is bound to invite the wrath of the entire capitalist international system.

In the dependency era, the former colony has been subjected to a barrage of competing forces, the economies of the former colonies have been fully integrated with the international capitalist market economy, making it almost impossible for the new nations to break loose from it even though the odds in the market are all against them. They have been incorporated into the world economic order as mere appendages. Two factors have made this possible: 
(i) proletarianization of African societies,

(ii) the peonage system imposed on them.

\section{Proletarianization}

This is a state in which all that Africans can offer is cheap labour. Proletarianization of Africans during the colonial epoch went side by side with semi-proletarianization. In other words, it was the process (and result) of generalized employment of wage labour in commodity production. Proletarian labour is one of the fundamental characteristics of capitalism in which workers are separated from their means of production, and sell their labour in the market to capitalists (owners of capital). The notion of ' generalized commodity production' (often used to describe capitalism) therefore suggests not only the generalized production of goods for sale but the employment of commoditized labour (i.e. wage labour) to do so. Proletarianization is based on economic compulsion; the forcible introduction of cash-crop farming and taxation were the forcemotrice of this process. Since one needed foreign currency with which to pay tax, one had to farm cash crops and sell to colonialists or offer one's labour to those colonialists who needed it for cash.

Semi-proletarianization was a process where people who had inadequate access to means of production, or had been dispossessed of such means, had to provide labour for others. One mechanism of semi-proletization was debt bondage in which producers provided labour because they had fallen in debt with their creditors over land rents, cash loans or other resources. Another type of semi-proletization occurred through periodic labour migration. Historically, semiproletization has involved a dimension of extra-economic coercion as well as economic compulsion. Current forms of semi-proletization may mirror characteristics of colonial forms but are generally regarded as being based on economic compulsion. Additionally, contemporary semi-proletization often combines production using one's own means of production with wage labour for local farms and industrial enterprises. The dispossession of the African of his land for colonial plantations rendered him semi-proletarianized.

The process of savage proletarianization runs as aptly stated by John Maleley, 'Competition between companies involved in manufacturing in developing countries is often ruthless. We are 
seeing what Korten described as "a race to the bottom. With each passing day it becomes more difficult to obtain contracts from one of the mega-retailers without hiring child labour, cheating workers on overtime pay, imposing merciless quotas, and operating unsafe practices" (Madeley 1999:103).

Having been made dependent on external sources for the satisfaction of even basic needs, the new nations have lost the capacity of feeding themselves, which they were well able to do with their indigenous farming methods. Take for example Nigeria which for ages was a food- surplus country. ${ }^{35}$ As of now, Nigeria, like other African nations, has to import grains and other agricultural products. The metropolitan countries supply to African nations not only manufactured goods but also foodstuff.

\section{The peonage system}

This debt system ensures continuing servitude of the former slaves after their proclaimed emancipation. In the system, the peons are paid below-subsistence wages; they can meet their very basic needs only by loans given them by their master. So the debts go on mounting and the servitude of the peons is perpetuated. ${ }^{36}$ According to Payer, the worker cannot run away, for other employers and the state recognize the legality of his debt: nor has he any hope of earning his freedom with his low wages, which do not keep pace with what he consumes, let alone the true value of what he produces for his master. ${ }^{37}$

According to Campaign Resource of April 2003, 'Every child in Africa is born with a financial burden which a lifetime's work cannot repay. This debt is a new form of slavery, as vicious as the slave trade'. Indeed, the All-Africa Conference of Churches estimates that Africa is the world's poorest region, and most of its people live on less than $\$ 1$ a day. But African countries owe $\$ 300$ billion in foreign debt.

It is the extension of this system of debt slavery to the emergent African states from the period of their political independence to the present day that has continued to ensure, and to worsen, their dependency status. For instance, Africa's debt rose sharply in the past decade and is now equivalent to over 100 percent of its gross national product. Debt servicing payments have soared and account for 3040 percent of the continent's export earnings which themselves are 
subject to commodity price decreases. It is estimated that by the year 2004, Sub-Saharan Africa will have to spend a staggering 70 percent of its export earnings on external debt servicing. This summary of debt data for sub-Saharan Africa is instructive:

(1) For every $\$ 1$ received in aid grants in 1999, sub-Saharan Africa paid back $\$ 1.51$ in debt service.

(2) Sub-Saharan Africa owes $\$ 231$ billion to creditors, that is $\$ 406$ for every man, woman and child in Africa.

(3) Sub-Saharan Africa bears 9 percent of the developing world's debts, but has only 5 percent of the developing world's income.

(4) Since 1996, sub-Saharan Africa has paid the IMF $\$ 1.2$ billion more than it has received.

(5) In 1999, sub-Saharan Africa paid $\$ 15.2$ billion in debt service. This works out at $\$ 42$ million a day.

(6) Sub-Saharan Africa spends over twice as much on debt service as on basic health care.

(7) Sub-Saharan Africa spends 6.1 percent of GNP on education and 5 percent on debt service. If Africa's debt were cancelled it could almost double its spending on education.

(8) Since 1990 debt service has risen from $\$ 10.9$ billion to $\$ 15.2$ billion, a rise of 39 percent.

(9) Sub-Saharan Africa's terms of trade has worsened steadily since 1980 , as commodity prices have fallen. The effect is to make the region 40 percent worse off in terms of its trade relations with the rest of the world.

(10) If Africa's export prices had kept pace with import prices since 1980, Africa could have repaid its debt twice over.

Given the fragile structure of Africa's economy, the debt burden is one of the continent's most crippling constraining factors. Any Action Research must aim at addressing the adverse consequences of the debt problem, in particular: (i) the reduction in the utilization rate of available productive capacity and the concomitant fall in output levels and fiscal revenues; (ii) the deterioration in the quantity and quality of public services in such crucial areas as education, health, transport and infrastructure as a result of reductions in government expenditure 
levels; and (iii) the fear of the tax implications of a heavy debt burden, which will induce domestic as well as foreign capital holders to invest outside the country, further exacerbating the shortage of investment funds. Many of these loans are illegitimate because:

- Many loans being repaid by African countries were made to Cold War era dictators whom Africa's people did not choose and who used the money to repress them. Example: In South Africa, the apartheid regime took out more than $\$ 18$ billion in foreign debt in its final 15 years in power. The victims of the apartheid regime should not now be forced to pay for their previous repression.

- Many loans being repaid by African countries were made to corrupt leaders who kept this money for themselves and added it to their own personal wealth. Example: In the Democratic Republic of the Congo, formerly Zaire, dictator Mobutu Sese-Seko received more US aid than the rest of sub-Saharan Africa combined during much of the Cold War, even though it was known that this money was being diverted into his Swiss bank accounts. The people of the DRC should not now have to pick up the tab for loans from which they saw no benefit.

- African countries' debts have swelled massively over time as a result of skyrocketing interest rates and harmful economic policies forced on these countries by creditors. Example: Nigeria originally borrowed $\$ 5$ billion from foreign governments and institutions. It has paid back $\$ 16$ billion, but its debt still stands at $\$ 32$ billion.

- African countries do not owe the US and European countries; these countries owe Africa for the wealth and resources they have stolen from the continent over centuries. Who really owes whom?

In sum, 'Debt is an efficient tool. It ensures access to other peoples' raw materials and infrastructure on the cheapest possible terms. Dozens of countries must compete for shrinking export markets and can export only a limited range of products because of Northern protectionism and their lack of cash to invest in diversification. Market saturation ensues, reducing exporters' income to a bare minimum while the North enjoys huge savings. The IMF cannot seem to understand that investing in ... [a] healthy, well-fed, literate 
population ... is the most intelligent economic choice a country can make' (George 1990: 143,187,235).

\section{Between Pan-African identity and globalization}

Kwame Nkrumah touched on the naughty question of Pan-African identity when he said: 'All Peoples of African descent, whether they live in North or South America, the Caribbean, or in any other part of the world are Africans and belong to the African nation'.

Pan-African identity is a truly complex as well as somewhat controversial issue. There is little agreement on precisely what constitutes an indigenous identity, how even to measure it, and who truly has that identity. Indeed, there is not even a consensus on appropriate terms to be used. Are we talking about Black people, African Americans, American Africans? Are we talking about race, ethnicity, cultural identity, acculturation, enculturation, bicultural identity, multi-cultural identity, or some other form of identity?

The issue of Pan-African identity opens a Pandora's box of possibilities, and to try to address them all may mean doing justice to none. This paper therefore concerns itself with three facets of identity: self identification, community identification, and external identification. But, our reflections shall be based on the shared sense of enslavement, exploitation and humiliation of people of African descent.

The current phenomenon called globalization has compounded the problem of Pan-African identity today. Globalization can be conceived as a process which embodies a transformation in the spatial organization of social relations and transactions, expressed in transcontinental or interregional flows and networks of activity, interaction and power. It is characterized by four types of change. First, it involves a stretching of social, political and economic activities across frontiers, regions and continents. Second, it is marked by the intensification, or the growing magnitude, of interconnectedness and flows of trade, investment, finance, migration, culture, etc. Third, it can be linked to a speeding up of global interactions and processes, as the development of world-wide systems of transport and communication increases the velocity of the diffusion of ideas, goods, information, capital and people. And, fourth, the 
growing extensity, intensity and velocity of global interactions can be associated with their deepening impact such that the effects of distant events can be highly significant elsewhere and specific local developments can come to have considerable global consequences. In this sense, the boundaries between domestic matters and global affairs become increasingly fluid. Globalization, in short, can be thought of as the widening, intensifying, speeding up, and growing impact of world-wide interconnectedness.

The present world is more tightly integrated than at any earlier point in history. In the age of the jet plane and satellite dish, the age of global capitalism, the age of ubiquitous markets and global mass media, the world is rapidly becoming a 'global village'. But, a perhaps even more striking aspect of the post-cold war world is the emergence - seemingly everywhere - of identity politics whose explicit aim is the restoration of rooted tradition, religious fervour and/or commitment to ethnic or national identities. African Renaissance, African Union, Afro-Pessimism, etc. are offshoots of this explosion of identities.

Globalization is a pervasive tendency influencing the lives of people everywhere since it entails essentially all the sociocultural processes that contribute to making distance irrelevant. It has important economic, political and cultural dimensions, as well as equally important ethical implications. Its processes affect the conditions of people living in particular localities, creating new opportunities and new forms of vulnerability. Risks are globally shared in the age of the nuclear bomb and potential ecological disasters. On the same note, the economic conditions in particular localities depend on events taking place elsewhere in the global system.

Patterns of consumption also seem to merge; people nearly everywhere desire similar goods. Naturally a precondition for this to happen is the implementation of certain institutional dimensions of modernity, notably that of a monetary economy - if not necessarily wagework and literacy. The ever-increasing transnational flow of commodities, be they material or immaterial, seems to create a set of common cultural denominators which threaten to eradicate local distinctions. Investment capital, military power and world literature are similarly being disembedded from the constraints of space; they no longer belong to a particular locality. In fact, with the 
development of the jet plane, the satellite dish and more recently, the Internet, distance no longer seems a limiting factor for the flow of influence, investments and cultural meaning.

At the same time, we have in recent years witnessed the growth, in very many societies in all continents, of political movements seeking to strengthen the collective sense of uniqueness, often targeting globalization processes, which are seen as a threat to local distinctiveness and self-determination. Many African countries have also seen a strong ethnification of their politics during the last decade, as well as the rise of political Islam in the north.

This new political scene, difficult to fit into the old left-right divide, is interpreted in very different ways by the many academics who have studied them. This is partly because identity politics comes in many flavours: Some are separatist nationalist movements; some represent historically oppressed minorities which demand equal rights; some are dominant groups trying to prevent minorities from gaining access to national resources; some are religious, some are ethnic, and some are regional. Many writers see identity politics in general as an anti-modern counterreaction to the individualism and freedom embodied by globalization, while others see it as the defence of the weak against foreign dominance, or even as a concealed strategy of modernization. Some emphasise the psychological dimension of identity politics, seeing it as nostalgic attempts to retain dignity and a sense of rootedness in an era of rapid change; others focus on competition for scarce resources between groups; some see identity politics as a strategy of exclusion and an ideology of hatred, while others see it as the child of socialism, as an expression of the collective strivings of the underdog.

Neither of these interpretations and judgements tells the whole story, both because the concrete movements in question differ and because the phenomenon of identity politics is too complex for a simple explanation to suffice. What is clear, however, is that the centripetal or unifying forces of globalization and the centrifugal or fragmenting forces of identity politics are two sides of the same coin, two complementary tendencies which must be understood well for anyone wishing to make sense of the global scene in the twentyfirst century.

For a variety of reasons, globalization creates the conditions for 
localization, that is various kinds of attempts at creating bounded entities - countries (nationalism or separatism), faith systems (religious revitalization), cultures (linguistic or cultural movements) or interest groups (ethnicity). For this reason, a more apt term, coined by sociologist Roland Robertson, might be glocalization. Some features that the 'glocal' identity movements of the turn of the millennium seem to have in common are:

First, identity politics always entails competition over scarce resources. Successful mobilisation on the basis of collective identities presupposes a widespread belief that resources are unequally distributed along group lines. 'Resources' should be interpreted in the widest sense possible, and could in principle be taken to mean economic wealth or political power, recognition or symbolic power - although what is usually primarily at stake are either economic or political resources.

Secondly, modernisation and globalization actualize differences and trigger conflict. When formerly discrete groups are integrated into shared economic and political systems, inequalities are made visible, since direct comparison between the groups becomes possible. In a certain sense, ethnicity can be described as the process of making cultural differences comparable, and to that extent, it is a modern phenomenon boosted by the intensified contact entailed by globalization. Nobody envies his neighbour if he is unaware of his existence.

Thirdly, similarity overrules equality ideologically. Ethnic nationalism, politicized religion and indigenous movements all depict the in-group as homogeneous, as people "of the same kind". Internal differences are glossed over, and for this reason, it can often be argued that identity politics serves the interests of the privileged segments of the group, even if the group as a whole is underprivileged, since it conceals internal class differences.

Fourthly, images of past suffering and injustice are invoked. To mention a few examples: Serbs bemoan the defeat at the hands of the Turks in Kosovo in 1389; leaders of the Hindu BJP have taken great pains to depict Mughal (Muslim) rule in India from the 1500s as bloody and authoritarian; and the African American movement draws extensively on the history of slavery. Pan-Africanism invokes images of enslavement, colonization and crass exploitation. 
Fifthly, the political symbolism and rhetoric evokes personal experiences. This is perhaps the most important ideological feature of identity politics in general. Using myths, cultural symbols and kinship terminology in addressing their supporters, promoters of identity politics try to downplay the difference between personal experiences and group history. In this way, it becomes perfectly sensible for a Serb to talk about the legendary battle of Kosovo in the first person ('We lost in 1389'), and the logic of revenge is extended to include metaphorical kin, in many cases millions of people. The intimate experiences associated with locality and family are thereby projected onto a national screen.

Sixthly, first-comers are contrasted with invaders. Although this ideological feature is by no means universal in identity politics, it tends to be invoked whenever possible, and in the process, historical facts are frequently stretched.

Finally, the actual social complexity in society is reduced to a set of simple contrasts. As Adolf Hitler already wrote in Mein Kampf, the truly national leader concentrates the attention of his people on one enemy at a time. Since cross-cutting ties reduce the chances of violent conflict, the collective identity must be based on relatively unambiguous criteria (such as place, religion, mother-tongue, kinship). Again, internal differences are undercommunicated in the act of delineating boundaries towards the frequently demonised person. Pan-Africanism thus must tackle global intrusions if it must survive as a relevant contribution to Africa's freedom in the third millennium.

\section{Africa: Exiting the global whirlpool?}

The starting point for understanding the world today is not the size of its GDP or the destructive power of its weapons systems, but the fact that it is so much more joined together than before. It may look like it is made up of separate and sovereign individuals, firms, nations or cities, but the deeper reality is one of multiple connections (Mulgan 1998:3).

Mulgan's assertion impels one to agree with Wallerstein that 'African development could only be the consequence of African strength, and that strength would come both from unity of action 
and from a recognition of the total worthiness of African culture, the total possibility of African achievement' (Wallerstein 1967: 27). The important question for Pan-Africanism is: how can Africa extricate itself from the modern highly digitized and militarized international system with its sophisticated and complex control network?

There is no simple answer to this question. History provides no parallel to the modern dependency-dominance syndrome. Today, the international system is much more integrated than even before, and, moreover, there is a commonality of interest among the major powers in the continued subjugation and exploitation of African societies, whatever the degree of rivalry between them for scarce and dwindling resources. If, therefore, African political economy desires to disengage itself from the international political economy, it faces a stupendous task.

However, the new Pan-Africanism must start by cleaning its house in Africa. First, the African army has to be solved. The African army is becoming less of a player on the political scene and that is the way it ought to be. At the threshold of the twenty-first century we must contemplate revamping the African army. The Information Age compels us to make the African military an informed and educated organic entity. Failure to do so may hamper African development. Soldiers of the new African army should have at least a high-school education and officers should have at the minimum American Junior college level education. The power of the army of the twentyfirst century will be centered on education and technology. In the twenty-first century concepts of defense will encompass more than the usual concept of the preservation of territorial integrity. The preservation and the enhancement of the environment will play an important role. For many countries of the Sahel, a security priority should be stopping the encroachment of the Sahara. At the global level, pollution, water scarcity, and environment degradation will be at the forefront of security issues. It then behooves Africans to have a military that can contribute to reduce these security risks. And this is possible only when the military becomes attractive to some of the best and the brightest youths in our societies.

The political class is another organic entity that is bound to have its power curtailed in the twenty-first century. Far from being a phenomenon confined to Africa, this will happen globally. The 
reason is very simple. The deeply cynical nature of the political class puts it at odds with the Information Age which at its core promotes transparence. Furthermore, the Information Age promotes education of the masses and as a result impacts the criteria of representation and the delegation of power.

In the twenty-first century the real, high quality power will be in the hands of a new African priesthood made of individuals capable of harnessing information and making a positive impact on the symbolic economy and the culture at large. These wizards of the Information Age will undoubtedly find themselves at odds with the current power structure that is fighting constantly for its survival and that of the status quo. Ultimately this new priesthood will prevail because they represent the future. In addition they will be in harmony with the new-networked economy referred to euphemistically as 'globalization'.

The challenge posed by globalization to the Pan-Africanist intellectual derives from the fact that it has powerful economic, political, cultural and social dimensions. In other words, globalization involves the diffusion of ideas, practices and technologies. It is more than internationalization and universalization. It certainly isn't just the liberalization of markets. Giddens (1990:64) has described globalization as 'the intensification of worldwide social relations which link distant localities in such a way that local happenings are shaped by events occurring many miles away and vice versa'. This involves a change in the way we understand geography and experience localness. As well as offering opportunity it brings with considerable risks linked, for example, to technological change.

This technological change has restructured the world in terms of:

- de-localization and supraterritoriality;

- the speed and power of technological innovation and the associated growth of risk;

- the rise of multinational corporations;

- the extent to which the moves towards the creation of (global) free markets leads to instability and division, especially deprived of the instruments of Knowledge Capitalism.

That is, in about the last twenty years of the twentieth century, a new economy emerged around the world based on Knowledge Capitalism that has three fundamental features: 
Productivity and competitiveness are, by and large, a function of knowledge generation and information processing; firms and territories are organized in networks of production, management and distribution; the core economic activities are global - that is, they have the capacity to work as a unit in real time, or chosen time, on a planetary scale. (Castells 2001:52)

In this era of globalization and knowledge economy productivity and competitiveness are, by and large, a function of knowledge generation and information processing. This has involved a major shift - and entails a different way of thinking about economies. That is to say,

For countries in the vanguard of the world economy, the balance between knowledge and resources has shifted so far towards the former that knowledge has become perhaps the most important factor determining the standard of living - more than land, than tools, than labour. Today's most technologically advanced economies are truly knowledge-based (World Bank 1998).

The rise of the so-called 'knowledge economy' has meant that PanAfrican intellectuals have been challenged to look beyond labour and capital as the central factors of production. Paul Romer and others have argued that technology (and the knowledge on which it is based) has to be viewed as a third factor in leading economies (Romer 1986; 1990). Global finance thus becomes just one force driving economies. Knowledge capitalism: 'the drive to generate new ideas and turn them into commercial products and services which consumers want' is now just as pervasive and powerful (Leadbeater 2000:8). Inevitably this leads onto questions around the generation and exploitation of knowledge. There is already a gaping divide between rich and poor nations - and this appears to be accelerating under 'knowledge capitalism'. There is also a growing gap within societies (and this is one of the driving forces behind the English government's 'Connexions strategy'). Scholars have argued for the need to 'innovate and include' and for a recognition that successful knowledge economies have to take a democratic approach to the spread of knowledge: 'We must breed an open, inquisitive, challenging and ambitious society' (Leadbeater 2000:235,237). This is the role of the Pan-African intellectual so that powerful counter-forces to this democratic knowledge ideal should not permit significant attempts by large corporations to claim intellectual rights over new discoveries, for example in relation to genetic research, 
and to reap large profits from licensing use of this 'knowledge'. This is the only way of exiting the whirlpool since the

central issue of contention is not globalization itself, nor is it the use of the market as an institution, but the inequity in the overall balance of institutional arrangements--which produces very unequal sharing of the benefits of globalization. The question is not just whether the poor, too, gain something from globalization, but whether they get a fair share and a fair opportunity (Sen 2002).

Strong markets require significant Pan-African state and transnational intervention. To be sustained across time strong capitalist markets also require stable social relationships and an environment of trust. Moreover, they can be organized and framed so that people throughout different societies can benefit. The assurance here lies in the nature of the capitalist world system itself.

Historically, free markets have been dependent upon state power. For markets to function over time they require a reasonable degree of political stability, a solid legal framework and a significant amount of social capital. The push to engineer free markets has contained within it the seeds of its own destruction.

The central paradox of our time can be stated thus: economic globalization does not strengthen the current regime of global laissez-faire. It works to undermine it. There is nothing in today's global market that buffers it against the social strains arising from high uneven economic development within and between the world's diverse societies. The swift waxing and waning of industries and livelihoods, the sudden shifts of production and capital, the casino of currency speculation - these conditions trigger political countermovements that challenge the very ground rules of the global free market (Gray 1999:7).

Capitalism is essentially disruptive and ever-changing - and takes very different forms across the world. While it produces wealth for significant numbers of people, many others have suffered. The gap between rich and poor has widened as global capitalism has expanded. Since Africa has been the permanent victim of these processes, its intellectuals have to develop tools for interpreting and changing the forces of this world system. Liberation theories of Pan-Africanism must benefit from this current situation created by global networks or perish. 


\section{Task for Pan-African Intellectuals}

Economic processes are no longer tied to distinct nation-states. Less so the African nation-state. This explains why 'globalization' is used with great frequency to describe complex processes and yet these uses are often uncritical of their ideological and methodological assumptions. Globalization should be viewed by the Pan-African intellectual in terms of communications' models, such as 'networks' to distinguish these signifying practices from those governed by more narrowly conceived linguistic and semiotic models, which were developed before the advent of the technologies partially responsible for the new globalization. These networks of transnational practice are: (a) corporate, (b) cultural, (c) technological, and (d) environmental.

These networks of globalization intersect in many crucial ways. In order to foreground possible overlaps between different global networks and thus articulate better what is meant at this stage by 'global forces', Pan-African intellectuals should apply three different methodological criteria to each of these four transnational networks. They should ask to what extent each of these global networks contributes to: decentering or recentering of the customary modes of scientific knowledge; new hierarchies and process of hierarchization, such as class, gender, race, and such formulations as 'first', 'second', and 'third world', diasporan, nationalism, local, and regionalism as metaphors for new social organizations.

Transnational corporate networks should be investigated in terms of their control over new forms of world-wide cultural dissemination, language circulation, consumerism, labour organization and finance. The way in which global economic and financial institutions have made African governments obsolete and exercise unchecked powers over peoples' lives of a magnitude unequalled in the past will provide a focus. They should also examine the paradoxes involved in the practices of these economic giants. How have they created hyperorganization on some levels of social and ecological life while producing unprecedented chaos on other levels? How has their supra-national power rendered obsolete traditional notions of social contract while leading to intensified claims of citizenship? How have they destablized traditional boundaries of class, ethnicity, 
gender, generation, and authority while creating new hierarchies and intensifying the polarizations between haves and have-nots on a worldwide scale? They will explore the contribution that critical theories can make on the one hand to understanding the role of institutions like the World Bank and the IMF and on the other hand to the experiences of migrantAfrican workers. They will therefore ask what kinds of theories can help us envision the as-yet-undiscovered political and social forms that would redistribute social power away from corporate control into more democratic relations in the continent.

The unstable, contested concept of culture looms large in many of the key debates that seek to define the present globalization moment, both within the academy and outside it. As an analytical concept, 'culture' has undergone major transformations in recent years, transformations that may most readily be identified as hybridization, creolization, multiculturalism, transnationalism, globalization. Further, such transformations at the level of the disciplines and media open up new, hitherto unmarked, links with political and social discourses throughout the world.

In dealing with this problematic they need to differentiate, first of all, two conceptions of culture, one allied to cultural studies and the other to anthropology: on the one hand, a cultural studies (or 'aesthetic') approach is oriented primarily to cultural products and expressive forms; on the other, the anthropological understanding of 'culture' is directed to the lifeworlds of people, to symbolic and cosmological systems. They would here be interested in exploring the increasingly important intersections between these two conceptions, and notably the ways in which such intersections are being determined through processes of globalization.

In the twenty-first century, many of the struggles over culture and globalization, purity and creolization, will take on new urgency. Practices of taxonomy and dissemination become determining in altogether new ways in areas like pedagogy, work and leisure, art and media, belief and ritual. They should be attentive both to the symbolic and political dimension of this process and thus to foreground ethical stakes that are implicit in the kinds of transformations we have outlined in the conceptualization of culture.

Both of the previous areas of investigation depend upon the study of how various technologies have contributed to the globalization of 
economies and cultures. Of technologies, they must be especially interested in communications' technologies, such as e-mail, video, fax, hypertext, internet, satellite, and film. They should be especially interested in the ways new technologies have resulted in new modes of commodification, both in terms of 'objects of consumption' and the more general 'object-relations' through which human subjects in part socially construct themselves. If the 'commodity' is, for example, no longer defined primarily through its materiality but rather through its discursive (or semiotic) functionality, then its mobility across national and other territorial borders is likely to be greater. In a related area, the 'the image' (lacking a better term at this stage of our project) takes the place of both the humanly constructed 'object' and the linguistic 'sign'. What is the phenomenology of the 'image' in a global framework, and to what extent does the 'image' function within or beyond the parameters of specific languages? In this latter regard, does 'image production' depend upon criteria of valuation, such as performative and communicative efficiency, that differ from the criteria governing a 'useful' object or 'meaningful' statement in language? More complex structures incorporating 'images' into narratives, such as 'virtual realities', will have to be examined similarly according to their implicit criteria for valuation.

New forces of globalization suggest variously coordinated transnational efforts in ecological awareness and environmental protection. These efforts are more needed in Africa today than ever before. These same forces suggest, however, technological transformations of 'Nature', such as in genetic engineering and the human genome project, that constitute yet another force of globalization: the thorough incorporation or subordination of Nature to social and economic domains. In this conext, the Pan-African intellectual would be particularly interested in studying assumptions of political responses to the globalization of environmental issues, ranging from specific political movements like the Green Party and its international offshoots, various eco-feminisms to the recent valorization of the local over the international, as well as just how such neo-regionalisms are configured in terms of a postmodern cosmopolitanism. Certain health issues are also relevant in this network, as they are in the cultural network, especially as epidemics and pandemics (such as $A I D S$ ) and environmental crises and disasters 
(such as damage to the ozone layer) shape transnational policies and thus contribute to what is understood in the phrase, forces of globalization.

There is not the least sign that globalization in its networks is leading to the historical obsolescence of the state. But neither does the present stage of history undermine the claim that the law of value necessarily operates in the world market over and above individual states. A Marxian theory of the state must thus explore the role of the state in furthering capital accumulation. This role includes a) enforcement of property rights, b) regulation of money, c) crisis management, d) provision of infrastructure, $R \& D$, training, and other 'public goods', and e) maintenance of access to necessary raw materials, markets, and so on. Globalization hardly erodes these essential state functions.

All the main forms of economic globalization - foreign direct investment (FDI), international trade, and flows of financial capital - require the enforcement of property rights. This remains the responsibility of states. FDI will occur only if states extend the same sorts of protections guaranteed under their system of jurisprudence to the holders of foreign investments. Regarding trade, in a world of rapid technological innovation the scope of intellectual property rights acknowledged and enforced by states becomes a matter of increasing importance. In the realm of finance capital, the state retains the capacity of decreeing which contracts are enforceable and which are not, a power that can affect which financial transactions occur in the global economy and which are not. The globalization of economic activity, and the specific paths taken in the course of globalization, are thus to a considerable extent a function of the power of states to define and enforce rights to property and exchange.

Money has always been the Achilles heel of the neoliberal dream of a self-sufficient free market. The reproduction of capitalist markets requires state activity regarding money. On the level of the global economy the same point holds. Even neoliberals hold that the satisfactory reproduction of the global economy over time requires appropriate monetary decisions by states, especially their central banks.

Of course defining what counts as an 'appropriate' monetary decision in a given context is a matter of great dispute. What is hardly in dispute, however, is that when crises break out in the 
global economy, governments must assume special responsibility to 'restore investor confidence'. In the continued absence of an international monetary agency with the power to create credit money, the responsibility for increasing liquidity in the global economy ultimately rests with national governments. Some states, at least, also retain a capacity to intervene to prevent losses to particular players from threatening global markets as a whole, as Alan Greenspan's organization of the bailout of Long Term Capital Management suggests. Further, investors continue to call on the state to 'socialize' the costs of global downswings by displacing them onto working men and women, the unemployed, the elderly, and so on. One mechanism for socializing these costs is through the state taking over private debts.

The extent to which particular regions enjoy success in the global economy today is to a considerable extent a function of their governments. Governments help create the conditions for regional success through support for education and training, funding for infrastructure and research, the formation of formal and informal networks of elites, government/business partnerships for specific projects of importance to regional growth, etc.

In the global economy access to foreign supplies of needed raw materials, foreign labour power and technologies, foreign markets for exported goods and services, foreign sources of capital, and so on, regularly requires state negotiation. Continued access may also regularly require military intervention by the state, or at least an effective threat of military action.

\section{Conclusion}

World capitalism has been undergoing a period of profound restructuring since the 1970 s bound up with the world historic process that has come to be known as globalization. One process central to capitalist globalization is transnational class formation, which has proceeded in step with the internationalization of capital and the global integration of national productive structures. Given the transnational integration of national economies, the mobility of capital and the global fragmentation and decentralization of accumulation circuits, class formation is progressively less tied 
to territoriality. The traditional assumption by Marxists that the capitalist class is by theoretical fiat organized in nation-states and driven by the dynamics of national capitalist competition and state rivalries needs to be modified since nowadays the capitalist class has organized itself at global level.

The transnational capitalist class (TCC) has emerged, and that this TCC is a global ruling class. It is a ruling class because it controls the levers of an emergent transnational state apparatus and of global decision making. This TCC is in the process of constructing a new global capitalist historic bloc; a new hegemonic bloc consisting of various economic and political forces that have become the dominant sector of the ruling class throughout the world, among the developed countries of the North as well as the countries of the South. The politics and policies of this ruling bloc are conditioned by the new global structure of accumulation and production. This historic bloc is composed of the transnational corporations and financial institutions, the elite that manage the supranational economic planning agencies, major forces in the dominant political parties, media conglomerates, and technocratic elites and state managers in both North and South.

In the process of globalization, all over the world Capital is chosen as the supreme ruler allowed to transmute the life of landscapes and forests, of animals and humans - the intactness of the entire biosphere - into vast amounts of money. These are then used solely to safeguard the continued self-gratification of a minority group in control of the means of power, the media and the financial centres, rather than in the service of the requirements of a healthy social existence of humanity together with all other life forms on earth. The result of this 'progress' is an increasingly desperate situation of a large part of the world's population and the decimation of the diversity of species. Corporations, markets, investors, and elites are going global. The globalization that is so often celebrated by economists, pundits, corporate executives, and the leaders of the world's richest nations is actually their 'globalization from above'. The danger of a new meta-narrative rooted in the language of globalization is that it denies the purposeful, creative, and, at times, powerful role Africans have played in the world capitalist system.

This globalization from above can and should be contested by a 
'globalization from below' through which people at the grassroots like those in Africa link up to impose their own needs and interests on the process of globalization. A movement embodying globalization from below is already emerging. Its global grassroots solidarity has the power to transform the world. Globalization gets mixed reviews. Greater interconnectedness among the world's people seems to promise a 'global village' in which the destructive antagonisms of the past can be left behind, replaced by global cooperation and enriching diversity. The advocates of a world without national economic barriers maintain that it will make everyone, including the people and countries at the bottom, better off.

But the actual experience of fin-de-millenium globalization has not fulfilled this promise. Instead, it has given us more poor people than the world has ever known and an increased threat to the environmental conditions on which human life itself depends. It has led many to fear the loss of hard-won social and environmental protections and even of meaningful self-government. Globalization from above is provoking a worldwide movement of resistance. While this movement has been gathering for years, many people first became aware of it in late 1999, when tens of thousands of protesters brought the Seattle meeting of the World Trade Organization to a halt. As The New York Times reported, 'The surprisingly large protests in Seattle by critics of the World Trade Organization point to the emergence of a new and vocal coalition' that included 'not just steelworkers and auto workers, but anti-sweatshop protesters from colleges across the nation and members of church groups, consumer groups, the Sierra Club, Friends of the Earth and the Humane Society' ${ }^{38}$

This movement is neither a one-shot nor a local phenomenon. As Elaine Bernard, executive director of the Harvard Trade Union Program, put it in the Washington Post, 'The WTO meeting was merely the place where these people burst onto the American public's radar. Social movements around the world had already linked into grass-roots networks, made possible by the astonishing speed at which they can communicate in the Internet era' ${ }^{39}$ Is such a movement futile, or can it actually affect the course of globalization? People can indeed exercise power over globalization, but only by means of a solidarity that crosses the boundaries of nations, identities, and narrow interests. A corporate-driven, top-down 
globalization can only be effectively countered by globalization from below. Fortunately, much of the movement that is emerging in response to globalization is showing just such a character. As Naomi Klein wrote in a New York Times op ed, 'The protesters in Seattle have been bitten by the globalization bug as surely as the trade lawyers inside the Seattle hotels... and they know it. This is the most internationally minded, globally linked movement the world has ever seen'. 40

Nonetheless, this movement is ambivalent about globalization. All of its participants share a commitment to resist globalization in its present form, but they differ on what should replace it. Some aim to roll back globalization and restore the - real or imagined - national economies of the past. Some present an agenda of modest reforms to correct globalization's worst excesses. Some are prepared to embrace a more interconnected, less nationally bounded world - but only one radically different from the 'actually-existing globalization' being created from above.

This movement can only succeed if it evolves from resistance, reform, and restoration to transformation - albeit a transformation that is rooted in today's resistance, that reforms institutions at every level, and that restores the elements of democracy, diversity, and ecological balance that globalization from above has destroyed. Such a transformation requires a multi-level strategy and program to impose new rules on the global economy while transferring wealth and power to ordinary people: a worldwide economic and political democratization.

Pan-Africanist-activist scholars must demonstrate their critical commitment in the central issues of globalization and their role in the production and dissemination of knowledge. They have a unique opportunity to challenge the inherited orthodoxies in both the academy and in the world in which we live. Their political commitment must fuel innovation in that they must explore some of the theoretical, conceptual, and empirical issues at stake, although we state as caveat that space constraints preclude a full discussion of these issues.

The propositions advanced here are intended to provoke discussion, and as a matter of course are tentative in nature, requiring further substantiation in ongoing research. In other words, they must 
continue to shape scholarly inquiry on such foundational issues as the origin and nature of slavery, the roots of underdevelopment, the meaning of sustainability, and the challenges of developing effective African democracy in the world capitalist system. On a theoretical level, they should insist on the explanatory power of class, gender, and a Pan-African perspective and emphasize identity politics. On the practical level, the Pan-African intellectual must demonstrate political commitment. This political commitment implies the promotion of human rights, involvement in anti-colonial and anti-imperialist campaigns, grassroots organizing, working in transnational NGOs, or speaking out as radical public intellectuals.

\section{Notes and references}

1. A new economic world order has emerged reaching an advanced stage of globalization: just 600 multinational corporations in 1991 had sales greater than US\$ 1 billion. They were responsible for at least 20 percent of the total worldwide industrial value added. See Mortimore, M., 'A new international industrial order: increased international competition in a centric world', in CEPAL Review, No. 48, 1992.

2. For the general advantages of this structural approach, see Smith, D. and White, D. 'Structure and dynamics of the global economy'. Social Forces, 1992, Vol. 70, No. 4, pp. 857-893; and Tilly, C. Big structures, large processes, huge comparisons, New York, Russell Sage, 1989).

3. In terms of concentration among nations: Latin America participated with 8 percent of the total international trade in 1960, for 1990, that participation is 4 percent, see G. Reyes, Globalization and Latin American Economies, Pittsburgh: University of Pittsburgh, 2000. See also C. Norris, 'The Wealth Gap Widens', Dollars and Sense, Sept./ Oct. 1999.

4. See B. Kaplan, Social change in the capitalist world, Beverly Hills, California, SAGE, 1993.

5. Under the present stage of the information-communications revolution, 10 multinational corporations control 65 percent of the world semiconductors market, 9 accounted for 89 percent of the world telecommunications market, and 10 others took care of the vast majority of the world computer market. See Maddison, A., Dynamic 
forces in capitalist development, Oxford, Oxford University Press, 1998, pp. 118-119.

6. These concepts are developed at greater length in M. Moore, Globalization and social change, New York, Elsevier, 1993.

7. Related to this issue is the significant power of multinational or transnational corporations. Data from 1997 shows that Mitsubishi Trading Co., Mitsui Co. and General Motors had sales equivalent to the economic size, in gross national product, of Indonesia, which is the $24^{\text {th }}$ economy of the world. These conditions lead to the evidence that certain parts of the world are undergoing processes of economic integration and desintegration. For more on these aspects see, Mundell, R., International Economics, New York, McMillan, 1998, especially the chapter concerning the theory of optimum currency areas, pp. 177-186; and Kenneth Galbraith, J. Challenges of the New Millennium talks with Asimina Caminis, in Finance and Development, 1999, Vol. 36, No. 4; and US Network for Global Economic Justice. (http://www.50years.org/).

8. For more on this issue see R. Lubbers, Globalization, economists and the real world, London:Tillburgh, 1999; R. Lubbers, Concepts on globalization, (http://www.globalize.org/publications/dynamic.html); and R. Blecker, Taming global finance, London, Economic Policy Institute, 1999.

9. See T. Levitt, The marketing imagination, New York, Free Press, 1986.

10. See P. Dickens, The global shift, New York, Guilford, 1998; and J. Foster, 'Contradictions in the universalization of capitalism' Monthly Review, 1999, Vol. 50, No. 11, p. 39.

11. See especially A. Portes, Labour, class, and the international system, New York, Aberdeen, 1992.

12. See M. Weber, Economía y sociedad, México, D.F., México, Fondo de Cultura Económica, 1987, especially pp. 8-16 and 23-54.

13. See a classic text on these issues in M. Weber, The Protestant ethic and the spirit of capitalism, New York: Scribner, 1988.

14. See concepts and examples of relationships between cultural aspects and communication in Etzioni.

15. See I. Wallerstein, The Modern World System, New York: Vintage Books, 1967; See also K. Marx, Capital, New York, New York International Publishers, 1967.

16. A.G. Hopkins, Economic History of West Africa, New York: Columbia University Press, 1973, p. 87.

17. For details, see E. Williams, Capital and Slavery, Capricorn Books, 
1966; Hopkins (note 3), pp. 78-117.

18. K. Marx (note 2), Capital, vol. 1, p. 714.

19. Ibid., p. 751 (emphasis added).

20. See A. Okolo, 'The role of International trade in the African political economy', in Shaw and Ojo, eds., Africa and the International Political System, University Press of America, 1982, pp. 68-103.

21. 21. See W. Rodney, How Europe Underdeveloped Africa, Tanzania Publishers House, 1973, pp. 103-162.

22. Hopkins (note 3), p. 117.

23. Ibid., pp. 117-118.

24. V. I. Lenin, Imperialism: the highest stage of capitalism, New York, New York International Publishers, 1966.

25. A.G. Hopkins, 'Economic Imperialism in West Africa 1880-1892', in Economic History Review , 1968, 21.

26. R. L. Pfaltzgraff, ed., 'Politics and the International System', $J B L$, (1972), pp. 206-207.

27. Sir A. Burns, The History of Nigeria, 1969, pp. 157-171.

28. I. M. Okonjo, British Administration in Nigeria 1900-1950, NOK Publishers, 1974.

29. A. Smith, An Inquiry into the Nature and Cause of the Wealth of the Nations, Modern Library Edition, 1937.

30. J. E. Flint, Sir George Goldie and the Making of Modern Nigeria, Oxford, Oxford University Press, 1960, pp. 69-73.

31. A. N. Cook, British Enterprise in Nigeria, London, Frank Cass, 1964, pp. $79-110$.

32. G. Barraclough, An Introduction to Contemporary History, London, Frank Cass, 1964.

33. F. Fanon, The Wretched of the Earth, New York, Grove Press, 1968, p. 39.

34. G.O. Olusanya, The Second World War and Nigerian politics 1939 1953, Lagos: University of Lagos Press, 1973, pp. 70-93; D.A.

Offiong, Imperialism and Dependency, Fourth Dimension Publishers, 1980, p. 65. See also H. M. Hodges, An Introduction to Sociology, New York: Harper and Row, 1971, pp. 99-125.

35. See A. Okolo, 'The Political Economy of the Nigerian Oil Sector and the Civil War', Quarterly Journal of Administration, Vol. XV, Nos. 1-2, 1981, p. 108.

36. S. Elkins, Slavery, Chicago: University of Chicago Press, 1971; A. Meier and E.M. Rudwick, From Plantation to Ghetto, Hill and Wang, 1969.

37. C. Payer, 'The Debt Trap, the IMF and the Third World', Monthly 
Review Press, 1974, p. 49.

38. Steven Greenhouse, 'After Seattle, Unions Point To Sustained Fight On Trade', New York Times, December 6, 1999, pA28.

39. Elaine Bernard, 'The Battle in Seattle: What was that all about?', Washington Post, December 5,1999, p. B1.

40. Naomi Klein, 'Rebels in Search of Rules', New York Times, 2 December 1999. See also Jeremy Brecher and Tim Castello, Global Village or Global Pillage: Economic Reconstruction from the Bottom $U p$, Cambridge: South End Press, 1998. For an introduction to this subject, see Sarah Anderson, John Cavanagh and Thea Lee, Field Guide to the Global Economy, New York: New Press, 2000. Point To Sustain Fight On 8 . "After Seattle, Unions Point To Sustained Fight on Trade" Steven Greenhouse.

\section{Bibliography}

Castells, M., 2001, 'Information technology and global capitalism' in W. Hutton and A. Giddens,eds., On The Edge. Living with global capitalism, London: Vintage.

George, Susan, 1990, A Fate Worse Than Debt, New York: Grove Weidenfeld.

Giddens, Anthony, 1990, The Consequences of Modernity, Cambridge: Polity Press.

Gray, J., 1999, False Dawn: The delusions of global capitalism, London: Granta.

Hochschild, Adam, 1998, King Leopold's Ghost: A story of greed, terror and heroism in colonial Africa, New York: Macmillan.

Jacques-Garvey, Amy, ed., 1970, Philosophy and Opinions of Marcus Garvey, New York: Atheneum.

Jensen, Katherine, 1984,'Civilization and Assimilation in the Colonized Schooling of Native Americans', in Gail P. Kelly and Philip G. Altbach, eds., Education and the Colonial Experience, New Brunswick: Transaction.

Kelly, Gail P. and Altbach, Philip G. 'Introduction: "The Four Faces of Colonialism"،, in Gail P. Kelly and Philip G. Altbach, eds., Education and the Colonial Experience, New Brunswick: Transaction.

Kesteloot, Lilyan, 1927, Intellectual Origins of the African Revolution, Washington, D.C: Orpheus Press, 1927. 
Macaulay, Thomas B. 'Minute on Indian Education'. (http://humanitas. ucsb.edu/users/raley/english/macaulay.html).

Madeley, John, 1999, Big Business Poor Peoples; The Impact of Transnational Corporations on the World's Poor, London, Zed Books.

Mulgan, G., 1998, Connexity: Responsibility, freedom, business and power in the new century, London: Viking.

Ngugi aa Thiong'o, 'The Global Education Process', (http://ultrix.ramapo. edu/global.thiongo.html).

Ngugi aa Thiong'o, 1981, Decolonising the Mind: The Politics of Language in African Literature, Portsmith: Heinemann.

Romer, Paul M., 1986, 'Increasing Returns and Long-Run Growth', Journal of Political Economy Vol. 94, No. 5.

Romer, Paul, 1990, 'Endogenous Technological Change', Journal of Political Economy Vol. 98, No. 5, pp. 71-102.

Sen, A., 2002, 'How to judge globalization', American Prospect Online. (http://www.prospect.org/print/V13/1/sen-a.html).

Smith, M. K., 2002, 'Globalization', The encyclopedia of informal education. (www.infed.org/biblio/globalization.htm).

Viswanathan, Gauri, 'Currying Favor: The Politics of British Educational and Cultural Policy in India, 1813-1854', Oxford Literary Review. Wallerstein, Immanuel, 1967, Africa: The Politics of Unity, New York: Vintage Books, 1967. 